\title{
Application of Ground Penetrating Radar Supported by Mineralogical-Geochemical Methods for Mapping Unroofed Cave Sediments
}

\author{
Teja Čeru ${ }^{1, *(\mathbb{D})}$, Matej Dolenec ${ }^{1}$ and Andrej Gosar ${ }^{1,2}$ (1) \\ 1 Faculty of Natural Sciences and Engineering, University of Ljubljana, Aškerčeva 12, 1000 Ljubljana, Slovenia; \\ matej.dolenec@geo.ntf.uni-lj.si (M.D.); andrej.gosar@gov.si (A.G.) \\ 2 Seismology and Geology Office, Slovenian Environment Agency, Vojkova 1b, 1000 Ljubljana, Slovenia; \\ andrej.gosar@gov.si \\ * Correspondence: teja.ceru@ntf.uni-lj.si; Tel.: +386-40-752-084
}

Received: 9 March 2018; Accepted: 17 April 2018; Published: 20 April 2018

\begin{abstract}
Ground penetrating radar (GPR) using a special unshielded $50 \mathrm{MHz}$ Rough Terrain Antenna (RTA) in combination with a shielded $250 \mathrm{MHz}$ antenna was used to study the capability of this geophysical method for detecting cave sediments. Allochthonous cave sediments found in the study area of Lanski vrh (W Slovenia) are now exposed on the karst surface in the so-called "unroofed caves" due to a general lowering of the surface (denudation of carbonate rocks) and can provide valuable evidence of the karst development. In the first phase, GPR profiles were measured at three test locations, where cave sediments are clearly evident on the surface and appear with flowstone. It turned out that cave sediments are clearly visible on GPR radargrams as areas of strong signal attenuation. Based on this finding, GPR profiling was used in several other places where direct indicators of unroofed caves or other indicators for speleogenesis are not present due to strong surface reshaping. The influence of various field conditions, especially water content, on GPR measurements was also analysed by comparing radargrams measured in various field conditions. Further mineralogical-geochemical analyses were conducted to better understand the factors that influence the attenuation in the area of cave sediments. Samples of cave sediments and soils on carbonate rocks (rendzina) were taken for X-ray diffraction (XRD) and X-ray fluorescence (XRF) analyses to compare the mineral and geochemical compositions of both sediments. Results show that cave sediments contain higher amounts of clay minerals and iron/aluminium oxides/hydroxides which, in addition to the thickness of cave sediments, can play an important role in the depth of penetration. Differences in the mineral composition also lead to water retention in cave sediments even through dry periods which additionally contribute to increased attenuation with respect to surrounding soils. The GPR method has proven to be reliable for locating areas of cave sediments at the surface and to determine their spatial extent, which is very important in delineating the geometry of unroofed cave systems. GPR thus proved to be a very valuable method in supporting geological and geomorphological mapping for a more comprehensive recognition of unroofed cave systems. These are important for understanding karstification and speleogenetic processes that influenced the formation of former underground caves and can help us reconstruct the direction of former underground water flows.
\end{abstract}

Keywords: ground penetrating radar (GPR); X-ray diffraction (XRD); X-ray fluorescence (XRF); karst; cave sediments; unroofed caves 


\section{Introduction}

Unroofed caves are surface karst features, the result of a general surface lowering originating from the dissolution of soluble rocks (denudation), mainly carbonates. They present the former underground features that are now exposed on the surface [1,2]. Unroofed caves as karst phenomena have been thoroughly studied mostly in Slovenia [1-7]. However, some international studies also describe these phenomena but mainly without speleological or geomorphological interpretations [8-11].

Many new findings were made in karstological science during motorway network constructions in Slovenia (see a review of all the research in the book edited by Knez and Slabe [12]). Many surface, epikarst and subsoil karst features were revealed during the construction works and over 350 new caves were opened in the Karst region, including unroofed caves [12]. Many karst features have been neglected, including unroofed caves in karst studies, therefore such research provides invaluable information and contributes to the fundamental knowledge of karstology. However, apart from karst investigations incorporated, for instance, in the earthworks preceding motorway construction, studying karst environment is mostly limited to observing features that are visible on the surface. Traditional destructive methods such as drilling and trenching are time-consuming, expensive and often unfeasible due to the rough and inaccessible karst terrain. Surface and underground features are closely linked and the pre-existence of underground karstification has conditioned the formation of surface features $[5,6]$, which is why geophysical methods in general and especially ground penetrating radar (GPR), are very useful non-invasive and relatively fast methods to provide subsurface information.

The term unroofed cave also includes flowstones and other allochthonous fluvial cave sediments that appear on the surface, even when caves are not morphologically expressed due to strong surface reshaping [2]. Since rock sculpturing and larger outcrops of flowstones as typical proofs of speleogenesis are usually absent, unroofed caves are often preserved only by their fine-grained alluvium material, the so-called "cave sediments." In such cases, geophysical methods used in favourable conditions can provide information about the presence of cave sediments on the surface and underground features related to unroofed caves. Unroofed caves and related sediment-filled karst features and their characterization have recently been successfully studied with GPR on Krk Island in Croatia [13]. Subsurface information obtained using a GPR with a $50 \mathrm{MHz}$ RTA (Rough Terrain Antenna) reveals that the valley-like depressions, irregular depressions completely or partially filled with sediment and some dolines are associated with a nearly $4 \mathrm{~km}$-long unroofed cave (developed as a result of karst denudation) [13].

Clastic cave sediments that encompass autochthonous and allochthonous cave sediments [14] have been the subject of many studies because they are important in paleoclimatic and paleogeographic reconstructions and help us understand the relationship between sedimentary and speleogenetic processes [14-19]. Although the objective of this paper is not to study the origin of the cave sediments, it should be noted that cave sediments can be of autogenic (originating from the cave) or allogenic (surface material transported with the stream flow) origin and are not homogeneous throughout the cave [20]. However, their mineral composition and origin are not easy to study. When cave sediments are exposed on the surface due to denudation processes, they are under the influence of intensive pedological processes [21]. Their mineralogical composition begins to change and their mineralogy turns out to be much more complex and heterogeneous.

Although GPR is widely used to investigate different soils, fewer studies observe the impact of the mineralogical and geochemical compositions of the soil on GPR results. Mineralogical and geochemical changes in composition can strongly affect the GPR effectiveness in the sense of the penetration of electromagnetic (EM) waves into the subsurface $[22,23]$. Conditions in the field can be very heterogeneous and many factors such as water content, grain size, mineralogical composition, organic-matter content and others may influence the propagation of the GPR signal in sediments [24]. These conditions can never be fully known when conducting GPR surveying in the field but complementary mineralogical analyses can provide very useful information for interpreting GPR images. Sediment properties in different karst 
areas can vary strongly, which means that a geochemical-mineralogical characterization should be done for each individual research area, which is time-consuming and requires additional funds.

The main goal of this research was to study the potential of the GPR method in detecting unroofed caves in regions where they are not morphologically expressed on the surface but partly revealed only by cave sediments preserved to a smaller extent. Because the research took place over a longer time period in different seasons, we also observed the influence of the various field conditions on GPR results. At the test location, the sampling of cave sediments and soils on carbonate rocks (rendzina) was carried out for geochemical and mineralogical analyses. They were completed in order to determine which factors might significantly influence GPR signal attenuation and lower the EM wave velocity.

\section{Study Area}

The study area (Lanski vrh) is located in the south-eastern part of the Planinsko polje, within the classical karst of western Slovenia (Figure 1) and is tectonically a part of the Adriatic carbonate platform. Planinsko polje extends along the Idrija strike-slip fault zone in the NW-SE direction. The wider surroundings of Planinsko polje are built of Upper Triassic dolomite as well as Jurassic and Lower and Upper Cretaceous carbonate rocks [25]. The study area of Lanski vrh consists mainly of Lower Cretaceous bituminous limestones with fossils (Requienia, Miliolidae) interbedded with grained dolomites and Upper Cretaceous rudist limestones and limestones with chert. The wider area is densely covered with solution dolines [26], with some collapse dolines (cave roof collapses appearing on the surface) visible as larger depressions on the LiDAR high resolution shaded relief image (Figure 1). Apart from all the mentioned features, there are many explored caves and also remnants of unroofed caves, which often appear at the (Cretaceous) limestone-dolomite contacts.

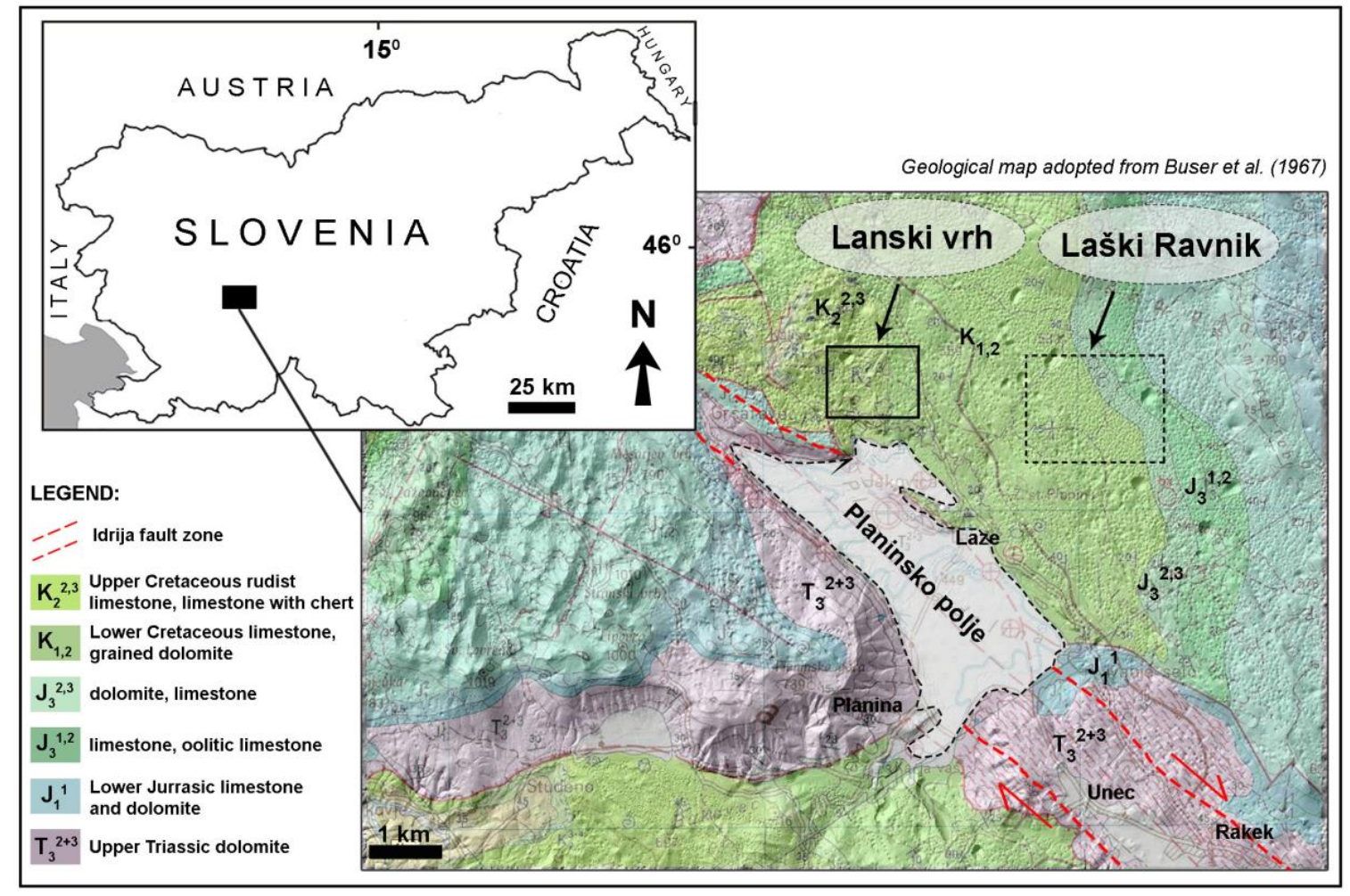

Figure 1. Location of the study area Lanski vrh and the basic geology [27] with the selected lithostratigraphic units of the narrow area on the LiDAR shaded relief image [28].

Cave sediments have already been systematically studied in the area of Laški Ravnik, which lies in the vicinity of our study area (Figure 1). Morphological and sedimentological indicators of unroofed 
caves, such as conglomerates, basal fills, flowstones, unroofed cave channels and openings of phreatic tubes were mapped in the area of Laški Ravnik [29]. The features now exposed on the surface were originally deep phreatic, oblique and relatively small with localized flowstone only [29].

Cave sediments in the study area (Lanski vrh) are mostly distinguishable by slightly yellowish or reddish colour compared to the brownish colour of the soil on carbonate rocks, the so-called "rendzina" (Figure 2a,b). In some places, we can find preserved flowstones (Figure 2c,d) that could be indicators for speleogenesis and septarian concretions, the latter being one of the most reliable indicators for speleogenesis. However, such indicators are generally not preserved in the area. Cave sediments can sometimes also be revealed by deepenings on forest roads, requiring the road surface to be frequently filled to keep it passable (Figure 3a). In these areas, water retention is evident, lasting even through dry periods in summer, so it is often necessary to dig gutters to drain the redundant water (Figure 3b).

The shape of the unroofed cave depends on the size, shape and type of the former underground cave, as well as on the incline of the surface which cut through the cave. A theoretical model of unroofed cave development is shown on the case of a simple horizontal cave passage (Figure 4). The underground passage developed in the first phase during karstification processes. In the second stage, the water table starts dropping, which results in the passage gradually becoming completely dry. During this stage, cave sediments are being deposited in the passage and speleothem growth begins. At some point, denudation reaches the passage and the cave starts to disintegrate, becoming a part of the surface topography. Therefore, cave sediments appear on the surface or are located right below the surface. In some places, the surface flowstone is well preserved but it mostly occurs locally in smaller pieces. Strong surface reshaping masks the primary form of the cave, which is why detecting cave sediments with GPR can help us follow and connect certain surface features into unroofed cave systems. The areas on which we focused in this study are presented in a simplified model (see the red ellipses in Figure 4).

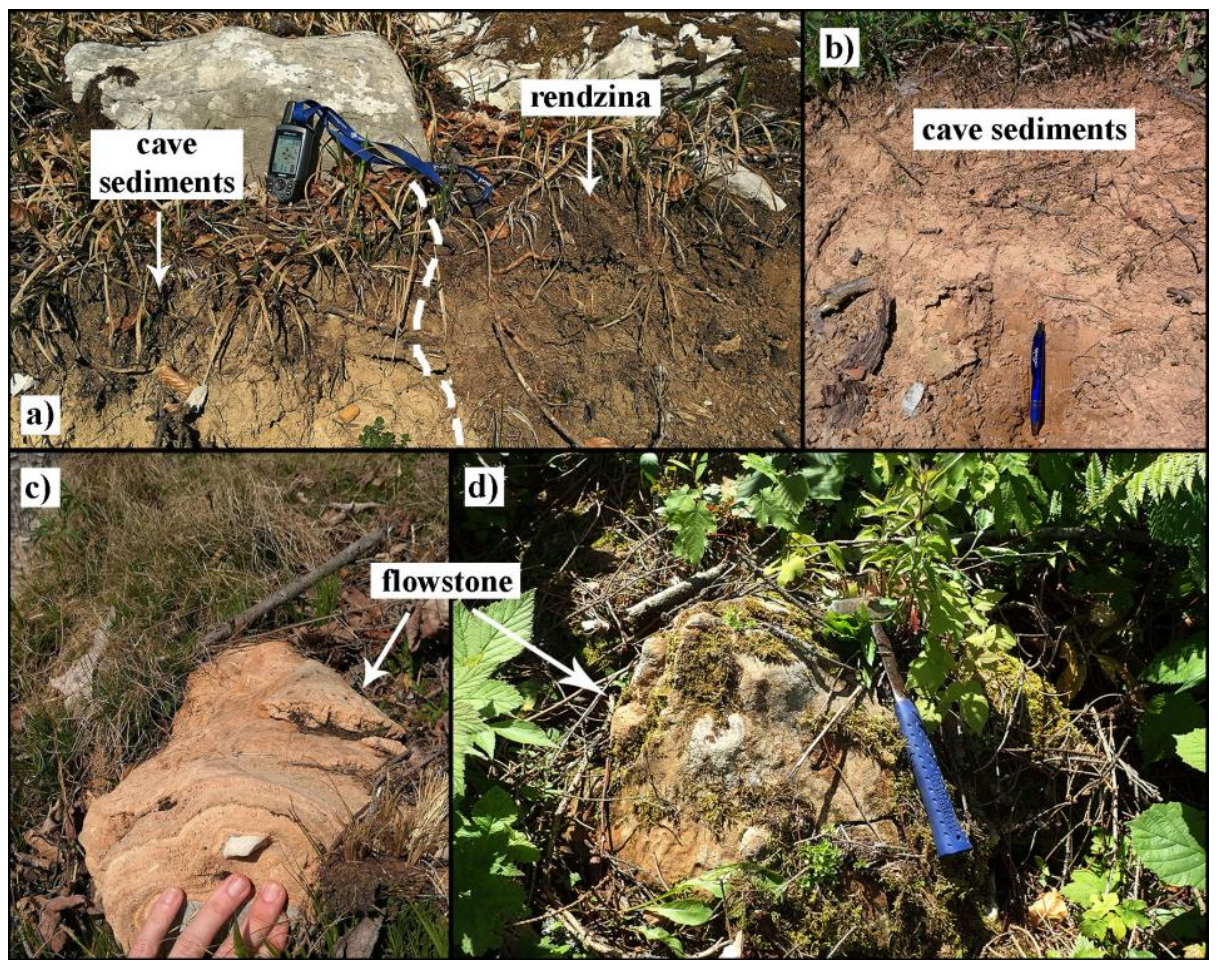

Figure 2. Cave sediments and flowstone as typical indicators for speleogenesis: (a) Comparison of the colour difference between cave sediments and soils on carbonate rocks (rendzina); (b) Closer view of the cave sediments; (c) Cave sediments are accompanied with occurrences of flowstone in some places; (d) Outcrops of flowstone are often covered with moss, making it easier to recognize them compared to outcrops of limestones. 


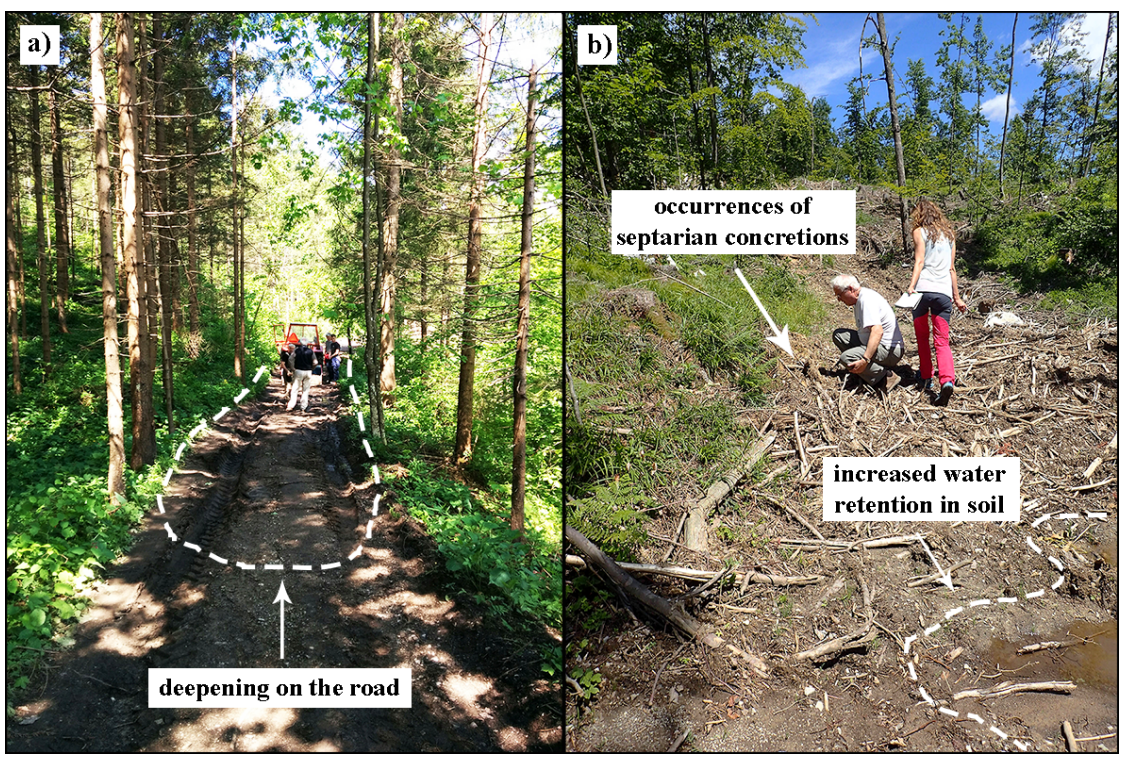

Figure 3. Indirect indicators for the possible presence of cave sediments: (a) Cave sediments are sometimes associated with surface deepening, so the road must be frequently filled to keep it passable; (b) Increased water retention in sediments even during dry periods is evident in certain places. In the area below the increased water retention septarian concretions were found as one of the most reliable indicators of speleogenesis.

\section{Simplified schematic model of unroofed cave development}

a) Formation of underground passage (phase 1), water table lowering, and deposition of cave sediments and speleothems (phase 2)

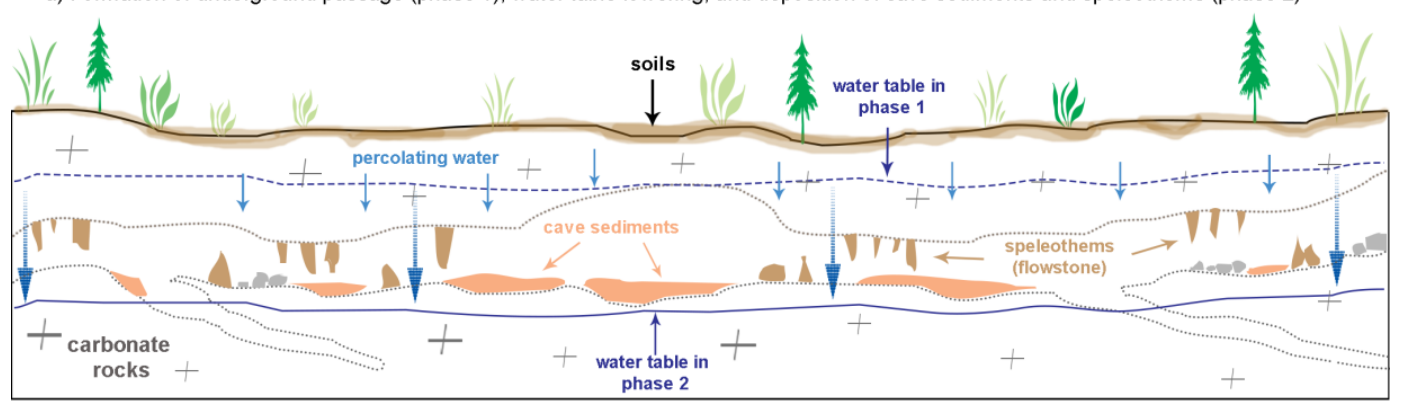

b) Denudation and surface reshaping

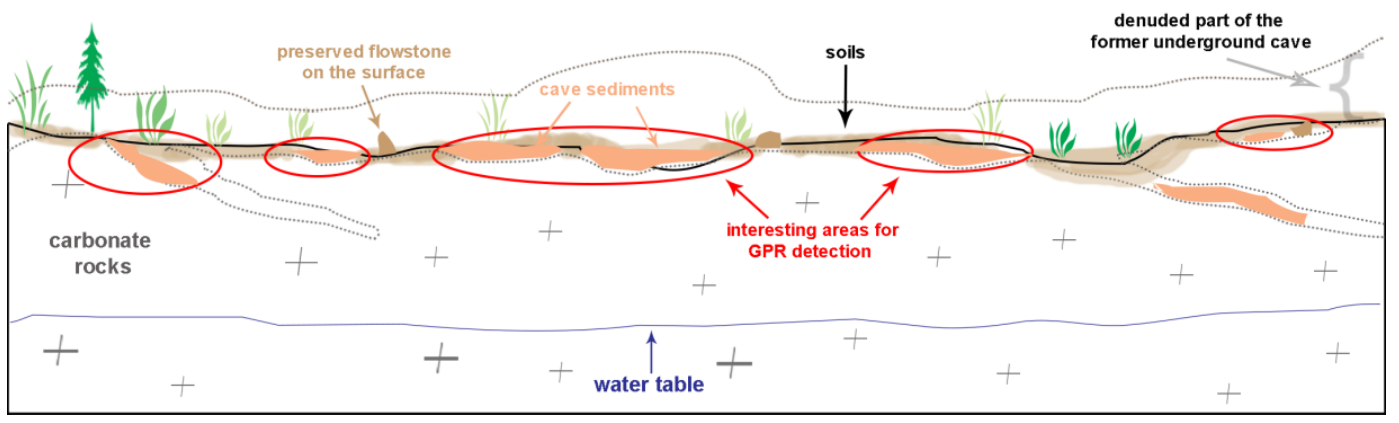

Figure 4. Schematic model of unroofed cave development: (a) Underground horizontal passage formed during karstification. When the water table started dropping, cave sediments were deposited and speleothems began to form. Dry passage filled with allochthonous and autochthonous sediments; (b) Denudation processes cut off the passage's upper parts, so cave sediments are revealed on the surface. Weathering and surface processes reshape the karst surface. 


\section{Materials and Methods}

First, we selected the locations of testing profiles where the presence of cave sediments was proven by direct indicators of speleogenesis such as flowstones, septarian concretions and the typical colour of cave sediments. We chose three such locations to test how the cave sediments are reflected on radargrams and to evaluate the GPR method for accurate characterizations of such areas. Profiles 1, 2 and 3 at testing locations (Figure 5) were measured where undeniable indicators proved the presence of cave sediments. At one test location (Profile 1), we obtained samples for further mineralogical-geochemical analyses to identify the possible differences in mineral composition between cave sediments and soils on carbonate rocks that can influence the GPR image.

After measuring the testing profiles, where cave sediments are clearly evident on GPR images as strongly attenuated areas, profiling was performed on other locations (Profiles 4, 5 and 6), where direct indicators for unroofed caves are absent or inadequate and appear only sporadically. We selected these locations to detect the spatial extent of cave sediments where there is no direct evidence for their presence, even though outcrops of flowstones and/or cave sediments are visible in the vicinity (Profiles 4 and 5). Occasionally, indirect indicators such as slight deepenings and water retention in sediments even during dry periods can indicate their presence. During the profiling, we marked all the possible signs for the presence of cave sediments on radargrams for an easier integration of GPR data and geomorphological mapping. Some profiles that are not presented in this study are given in orange lines in Figure 5.

Since the extensive research also included other research issues which took place over a longer period of time, we conducted the GPR surveys in various field conditions in different seasons (see Table 1). In this paper, only radargrams of Profiles $1,2 \mathrm{a}$ and $2 \mathrm{~b}$ are presented, measured in various field condition. Most of the profiles were measured in dry periods to avoid additional attenuation in wet field conditions.

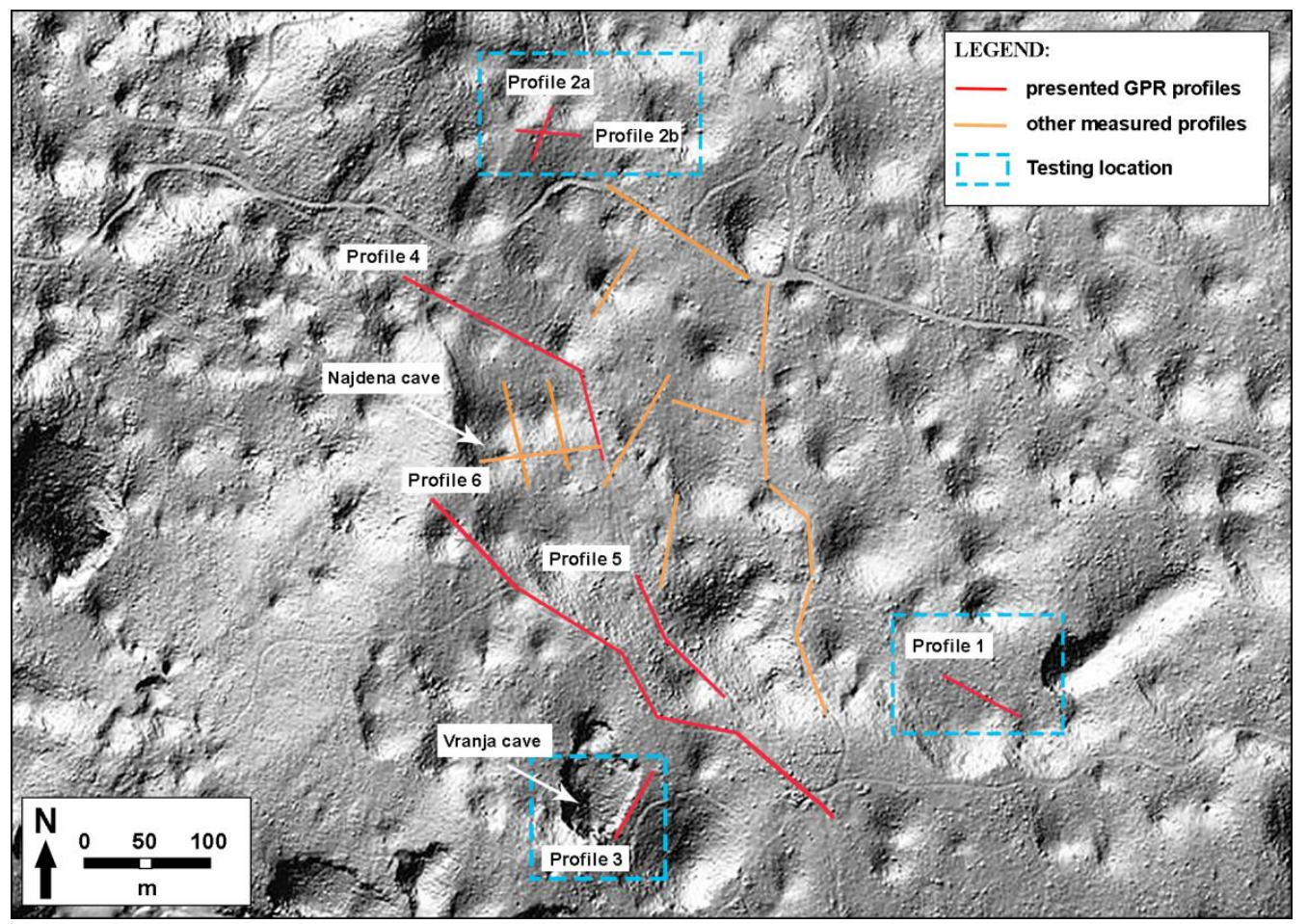

Figure 5. Locations of ground penetrating radar (GPR) profiles at the investigated area on the LiDAR shaded relief image. Testing locations (blue rectangles) were chosen where cave sediments and flowstone occur on the surface. 
Table 1. Presented profiles with basic characteristics.

\begin{tabular}{|c|c|c|c|c|c|c|}
\hline Profile & $\begin{array}{c}\text { Antenna } \\
\text { Frequency }\end{array}$ & $\begin{array}{c}\text { General } \\
\text { Direction }\end{array}$ & $\begin{array}{c}\text { Period of } \\
\text { Measuring }\end{array}$ & $\begin{array}{c}\text { Field } \\
\text { Conditions }\end{array}$ & $\begin{array}{l}\text { Indicators for the Presence of } \\
\text { Cave Sediments }\end{array}$ & \\
\hline Profile 1 & 50 and 250 & SE-NW & $\begin{array}{c}\text { July } 2016 \\
\text { March } \\
2017\end{array}$ & $\begin{array}{l}\text { very dry } \\
\text { dry }\end{array}$ & colour of sediments, flowstone & \multirow{7}{*}{$\begin{array}{l}\text { Testing } \\
\text { Profiles }\end{array}$} \\
\hline Profile 2a & 50 and 250 & SSW-NNE & $\begin{array}{c}\text { March } \\
2017 \\
\text { January } \\
2018\end{array}$ & $\begin{array}{c}\text { dry } \\
\text { moderately wet }\end{array}$ & $\begin{array}{l}\text { colour of sediments, small pieces } \\
\text { of flowstone }\end{array}$ & \\
\hline Profile $2 b$ & 50 and 250 & $\mathrm{E}-\mathrm{W}$ & $\begin{array}{c}\text { March } \\
2017 \\
\text { January } \\
2018\end{array}$ & $\begin{array}{c}\text { dry } \\
\text { moderately wet }\end{array}$ & $\begin{array}{l}\text { colour of sediments, small pieces } \\
\text { of flowstone }\end{array}$ & \\
\hline Profile 3 & 250 & SSW-NNE & July 2016 & very dry & colour of sediments, flowstone & \\
\hline Profile 4 & 50 and 250 & $\begin{array}{l}\text { SSE-NNW, } \\
\text { ESE-WNW }\end{array}$ & $\begin{array}{l}\text { January } \\
2018\end{array}$ & moderately wet & $\begin{array}{l}\text { deepening on the road, water retention, } \\
\text { septarian concretions in cave sediments }\end{array}$ & \\
\hline Profile 5 & 250 & NNW-SSE & July 2016 & very dry & deepening on the road, water retention & \\
\hline Profile 6 & 50 & SE-NW & July 2016 & very dry & flowstone at one location & \\
\hline
\end{tabular}

In the second stage of the research, at the location of Profile 1 (Figure 5), we drilled three boreholes with auger drilling equipment to collect the samples for the X-ray diffraction (XRD) and $\mathrm{X}$-ray fluorescence (XRF) analyses. Borehole V1 and V2 were located in the area of cave sediments, while borehole V3 (at a distance of $10 \mathrm{~m}$ from borehole V2) was located in the soil on carbonate rocks (rendzina). Manual drilling into cave sediments was possible to the depth of $85 \mathrm{~cm}$ in V1 and 95 $\mathrm{cm}$ in V2. The depth of $85 \mathrm{~cm}$ in V3 represents the contact between soil and the carbonate bedrock. Samples were collected every $20-35 \mathrm{~cm}$. The colour of samples by depth is shown in Table 2 .

Table 2. The soil colour of the samples.

\begin{tabular}{|c|c|c|c|}
\hline & Sample & Depth $(\mathrm{cm})$ & Colour (Munsel Soil Chart) \\
\hline \multirow{3}{*}{ cave sediments V1 } & 1V1 & $0-20$ & 7.5YR 5/6-7.5YR 5/8 \\
\hline & 2V1 & $20-50$ & 5YR $3 / 4$ \\
\hline & $3 \mathrm{~V} 1$ & $50-85$ & $5 Y R 3 / 4$ \\
\hline \multirow{4}{*}{ cave sediments V2 } & 1V2 & $0-20$ & $7.5 Y R 4 / 4$ \\
\hline & $2 \mathrm{~V} 2$ & $20-40$ & 5YR 4/4 \\
\hline & $3 \mathrm{~V} 2$ & $40-70$ & $5 \mathrm{YR} 4 / 4$ \\
\hline & $4 \mathrm{~V} 2$ & $70-95$ & 5YR $4 / 4$ \\
\hline \multirow{3}{*}{ soil on carbonate rocks (rendzina) V3 } & $1 \mathrm{~V} 3$ & $0-20$ & 10 YR $5 / 3$ \\
\hline & $2 \mathrm{~V} 3$ & $20-50$ & $10 Y R 4 / 3$ \\
\hline & $3 \mathrm{~V} 3$ & $50-85$ & 10YR 4/4-10YR 4/6 \\
\hline
\end{tabular}

\subsection{Ground Penetrating Radar (GPR)}

The number of various applications of the GPR method has increased in the past 20 years along with the number of studies examining various issues in karst environments. This indicates a wide range of potential uses for the GPR method in the last ten years [30-34]. GPR as a high-resolution geophysical technique has also been widely used in soil surveys to estimate taxonomic composition, to detect diagnostic soil horizons and evaluate their depth, to assess variations in soil properties, to determine soil water content and to determine subsurface flow pathways and water table [35-42]. The most commonly used antennas for soil investigations regarding the soil condition and subsurface features are those with centre frequencies between 100 and $500 \mathrm{MHz}$ or lower-frequency antennas if the soils cause high attenuation [43]. Apart from the many mentioned applications of the GPR method, its use in karst environments has been one of the most successful applications [44]. 
In our study, we used the ProEx (MALA Geoscience, Sweden) GPR with a $50 \mathrm{MHz}$ unshielded Rough Terrain Antenna (RTA) and a shielded $250 \mathrm{MHz}$ antenna to observe the information obtained by measuring with two different frequencies and systems (shielded and unshielded).

Profile measurements were carried out along macadam roads or forest paths due to the even and cleared terrain, which allows better ground contact for the antenna and thus provides higher-quality data. The survey was performed during various field conditions but we obtained the major part of the measurements in dry periods to minimize the influence of moisture on signal attenuation in sediments, which can be inherently strongly conductive depending on their mineralogical composition. When studying regolith bodies (the term regolith as suggested by Šušteršič [26] covers the great variety of heterolithic sedimentary bodies in karst environments when their origin is not known), which are known as highly conductive, sediments properties should be known for a consistent and certain interpretation of the GPR data. However, karst is one of the most complex and unpredictable environments, where features are very heterogeneous and the soil/bedrock interface is uniform, which represents a challenge for geophysical exploration [45]. Therefore, any additional information about the subsurface constitute an important contribution in the interpretation of geophysical data.

All profiles were processed and analysed using the Reflex-Win software of Sandmeier Geophysical Research. The following processing steps were employed: editing, subtract-mean (dewow), time zero correction, background removal, gain (manually-defined exponential corrections) and bandpass filtering. Lastly, we used subtracting average to eliminate periodic ringing noise and applied topographic correction where necessary. The raw data and the two radargrams that include some processing steps are presented on the case of Profile 1 (Figure 6). Various gain functions were applied to profiles in order to achieve a good visualization of the GPR images. Energy decay and automatic gain control (AGC) with different time windows were applied first but were not sufficient. Only the manually-defined exponential corrections, where the operator can emphasize the signal in the areas of assumed structures gave the most effective results.

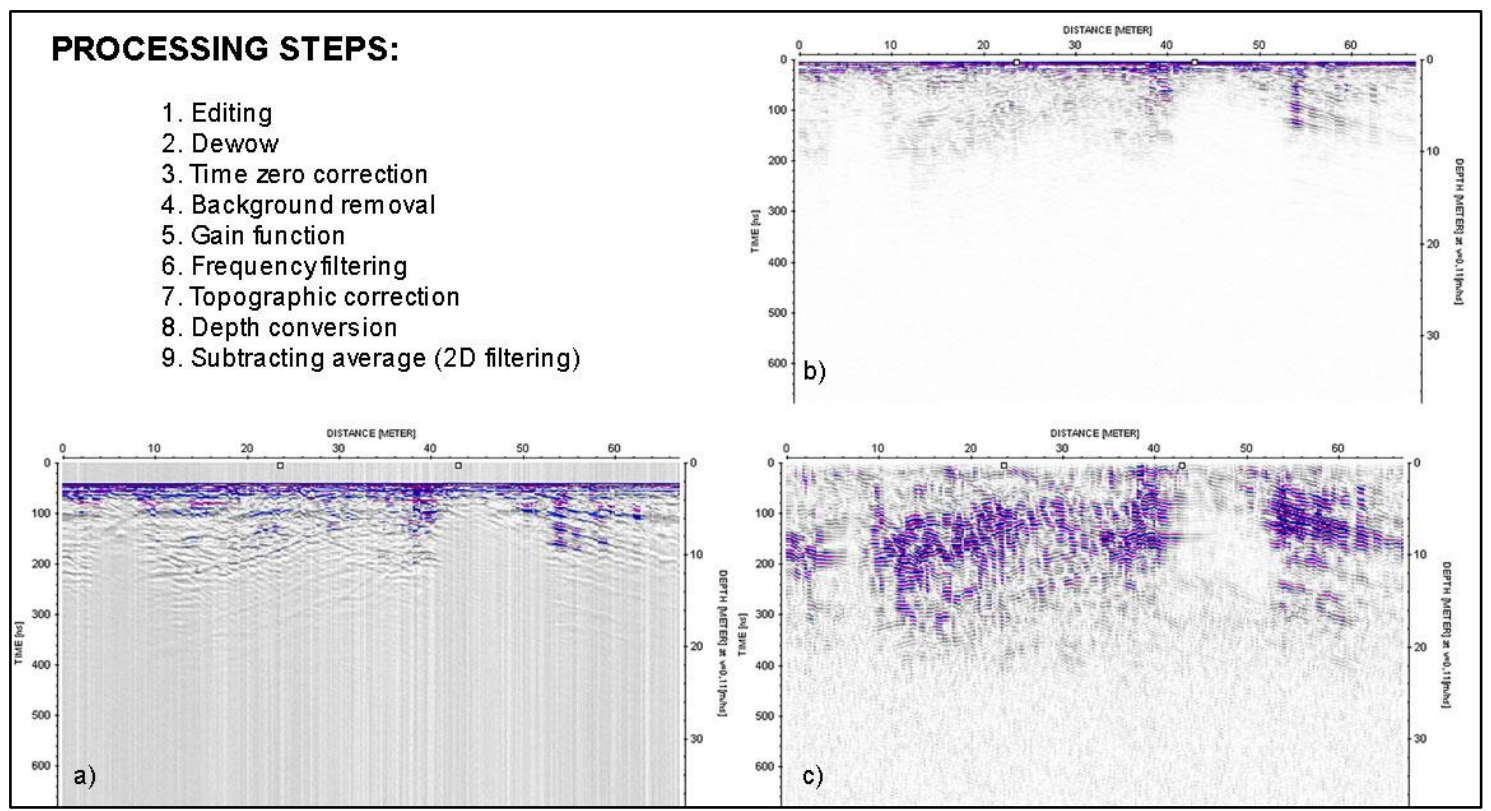

Figure 6. Processing steps (1-9) applied in profiles. Raw data and some processing steps are presented for Profile 1: (a) Raw data; (b) After dewow and time zero correction; (c) After background removal, manually-defined exponential gain correction, frequency and 2D filtering. 


\subsection{X-ray Diffractometry (XRD)}

To characterize the crystalline minerals of the samples, we applied X-ray powder diffraction using a Philips PW3710 X-ray diffractometer equipped with CuKa radiation, a proportional counter and a secondary graphite monochromator operated at a voltage of $40 \mathrm{kV}$ with a filament current $30 \mathrm{~mA}$. Scanning speed was $3.4^{\circ} 2 \theta$ per minute in the range from $2^{\circ}$ to $70^{\circ} 2 \theta$.

Clay minerals were identified from the clay fractions of bulk samples obtained from an oriented glass slide using a combination of a kitchen-grade blender, an ultrasonic probe and ultracentrifugation [46]. The following diagnostic treatments were carried out for all the samples: ethylene glycol solvation at $70{ }^{\circ} \mathrm{C}$ overnight, glycerol solvation at $70{ }^{\circ} \mathrm{C}$ and heating to $550{ }^{\circ} \mathrm{C}$ for $2 \mathrm{~h}$ each. Diffraction patterns were identified with X'Perth HighScore Plus 4.6a software using the PAN-ICSD database and Rietveld refinement that applied the Pseudo-Voigt function for quantitative mineral phase analysis.

\subsection{X-ray Fluorescence (XRF)}

The elemental composition of the samples was measured by the XRF method with a handheld ThermoFisher NITON XL3t-GOLDD 90S-He analyser using the factory setting Mining mode. We determined the presence of $\mathrm{Si}, \mathrm{Al}, \mathrm{Fe}, \mathrm{Mg}, \mathrm{Ca}, \mathrm{K}, \mathrm{S}, \mathrm{Cu}, \mathrm{Mn}, \mathrm{Mo}, \mathrm{Nb}, \mathrm{Pb}, \mathrm{Rb}, \mathrm{Sr}, \mathrm{Zn}, \mathrm{Zr}, \mathrm{Ti}$ and $\mathrm{Ba}$. During the measurements helium gas was supplied at the analysed site for better light elements (Mg to $\mathrm{S}$ ) energy detection. At the beginning and at the end of sample measurement, accuracy and precision were assessed against pre-calibration with 24 international standards (NIST and USGS) and calibration with NIST-1d and NIST-88b. To better constrain the relationship between elemental and mineralogical variability among the samples, statistical analyses (PCA-principal component analysis) were performed using STATISTICA 8.0 and Grapher 10.0 software.

\section{Results}

\subsection{GPR Results at Testing Locations}

At the three test locations (Figure 5), the typical yellowish or reddish colour of cave sediments and outcrops of flowstones prove that we are researching the remnants of a former underground cave. Some profiles are presented by comparing the results obtained with different frequencies (Profiles 1, 2a, 2b, 4). Areas with higher wave attenuation related to larger regolith bodies including cave sediments are clearly visible on both radargrams recorded with the $50 \mathrm{MHz}$ antenna as well as with the $250 \mathrm{MHz}$. Therefore, measurements of Profiles 3, 5 and 6 are presented only by a one-frequency GPR image ( 50 or $250 \mathrm{MHz}$ ).

At the testing location of Profile 1, we obtained measurements where cave sediments and flowstone occur on the forest path (Figure 7a). Attenuation resulting in the absence of reflections is clearly visible both on $50 \mathrm{MHz}$ and $250 \mathrm{MHz}$ images (Figure $7 \mathrm{~b}, \mathrm{c}$ ). Penetration of the signal is completely restricted in the area of cave sediments, compared to its surroundings where the depth of penetration for the $50 \mathrm{MHz}$ and $250 \mathrm{MHz}$ antennas reached approximately 15-20 m and 4-8 m, respectively. In the area of cave sediments, we drilled boreholes V1 and V2 to the depth of $85 \mathrm{~cm}$ and $95 \mathrm{~cm}$, respectively (Figure 7d). The depth of the boreholes does not represent the total thickness of cave sediments because manual drilling with an auger was impossible to greater depths. The signal in the area of borehole V3 (Figure 7e), where the contact between soil and the bedrock occurs at the depth of $85 \mathrm{~cm}$, is not as attenuated as in the area of cave sediments (see the comparison of signal amplitudes in Figure 7c).

In the area of Profiles $2 a$ and $2 b$ (Figure $8 a$ ), cave sediments were revealed on the surface by a fallen tree where the roots brought up underground material. In addition, we can find pieces of flowstone in the vicinity. Two profiles were measured in two directions perpendicular to each other to detect the spreading of the cave sediments. Radargram of Profile 2a clearly shows the direction and extent of cave sediments, where signal is strongly attenuated (Figure $8 b, c)$. The attenuated area in the radargram of Profile $2 \mathrm{~b}$ is limited to the outcrops of cave sediments on the surface which indicates that the direction of this profile was oriented transversally to the spatial extent of the sediments (Figure 8c). 

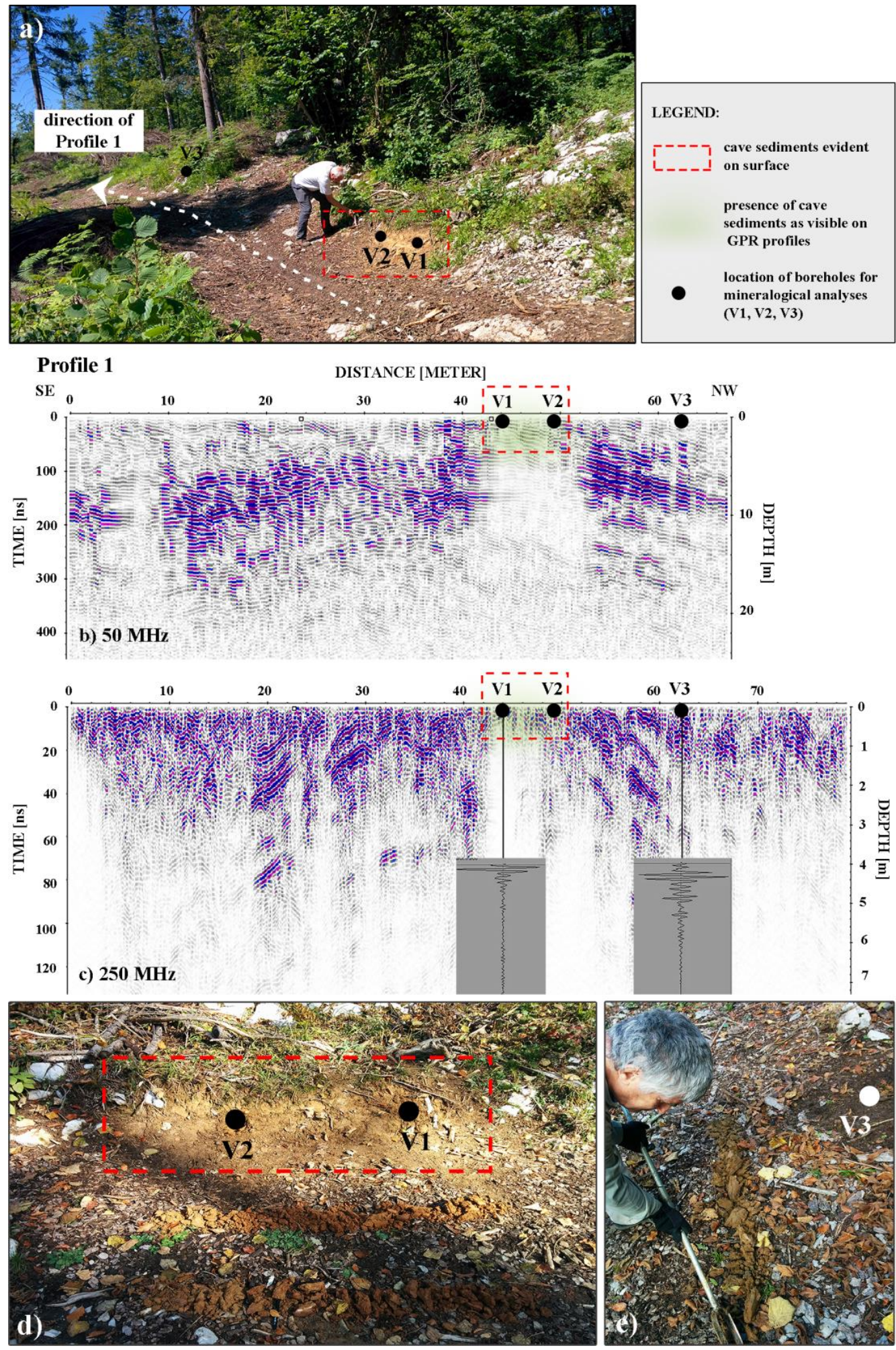

Figure 7. (a) Direction of Profile 1 acquired over an area of cave sediments; (b) A processed radargram with highly attenuated area presenting cave sediments with $50 \mathrm{MHz}$ antenna and (c) with $250 \mathrm{MHz}$ antenna (vertical exaggeration 1:4); (d) Locations of V1 and V2 boreholes in cave sediments; (e) Sampling with a manual drilling machine in soils on carbonate rocks (V3). 

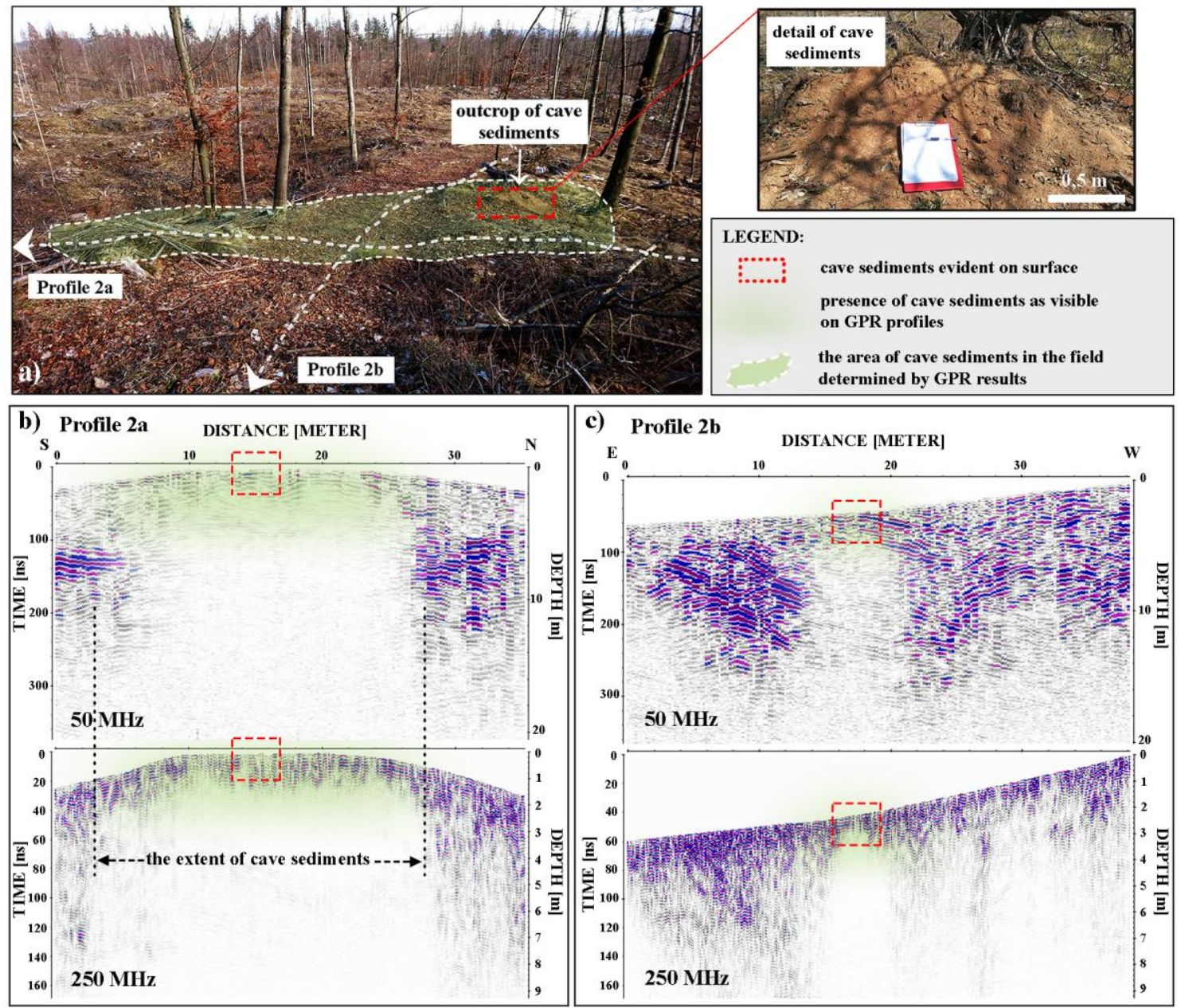

Figure 8. (a) Direction of perpendicular Profiles $2 \mathrm{a}$ and $2 \mathrm{~b}$ recorded with a 50 and $250 \mathrm{MHz}$ antenna (vertical exaggeration of the $250 \mathrm{MHz}$ GPR images is 1:2) in the area of the cave sediments outcrop to determine their spatial extent; (b) Extent of cave sediments was determined in Profile 2a; (c) Boundaries of cave sediments detected by GPR are limited to the area of the outcrop visible on the surface.

Larger attenuated areas restricted to $22 \mathrm{~m}$ in length in the areas of Profiles $1,2 \mathrm{a}$ and $2 \mathrm{~b}$, as visible on the radargrams, suggest that these areas are related to cave sediments, where pieces of flowstone also indicate their presence. Geomorphologically, these areas are relatively flat with an elevated surrounding relief. They could represent the very last surface manifestation of the segments of the unroofed cave system and cave channels, like the ones visible in the nearby area of Laški Ravnik (see Figure 3 in [29]). An additional sign for identifying unroofed caves are the geomorphological features of the surrounding terrain. Depending on the cave type and the manner in which denudation cut the cave, unroofed caves can appear as elongated dolines, series of dolines, shafts or linear to irregular depressions completely filled with sediments [2,6,7]. Apart from that, surface processes can strongly reshape and modify the segments of the former cave, so they are sometimes completely masked, meaning that their speleogenetic origin cannot be demonstrated.

In the area of Profiles 1, 2a and 2b, an elongated depression (Figure 9a) and series of dolines with intermediate ridges (Figure $9 b$ ) support the existence of segments of unroofed cave in these areas. 


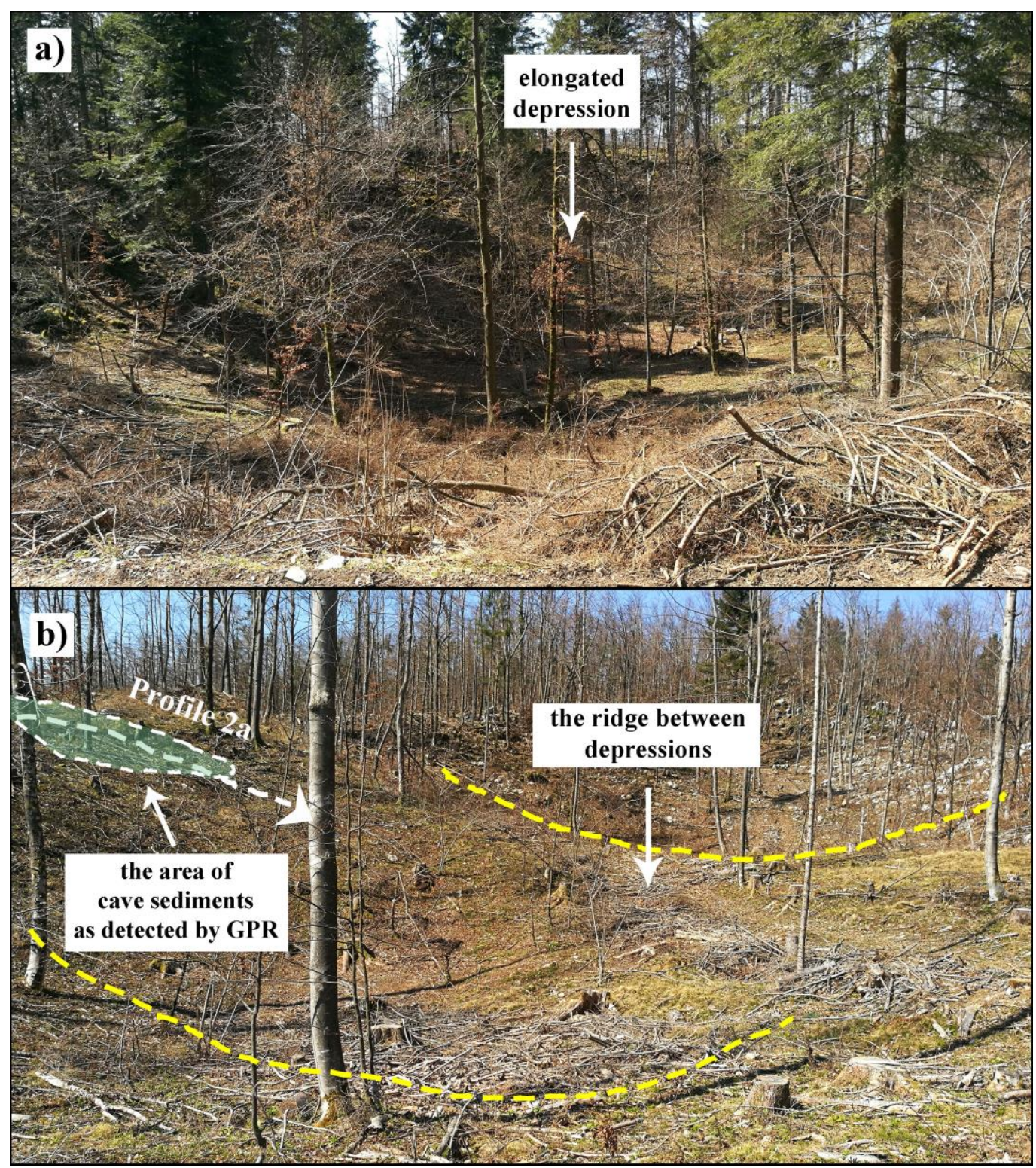

Figure 9. Surface topography in the vicinity of detected cave sediments: (a) An elongated depression at the location of Profile 1; (b) The surface morphology in the area of Profiles 2a and 2b, where depressions pass from one to another with intervening small ridges.

The last test location is situated in the vicinity of the collapse doline which is also the entrance to the Vranja cave. Profile 3 was measured in the area of a flowstone outcrop and the processed profile revealed a large attenuated area which extends over the larger area beyond the measured line (Figure 10). The penetration of the signal is completely restricted (distance 6-50 m) compared to its surroundings where the depth of penetration for the $250 \mathrm{MHz}$ antenna reached to the approximate depth of 6-7 $\mathrm{m}$, which can be seen at the beginning of the profile. 


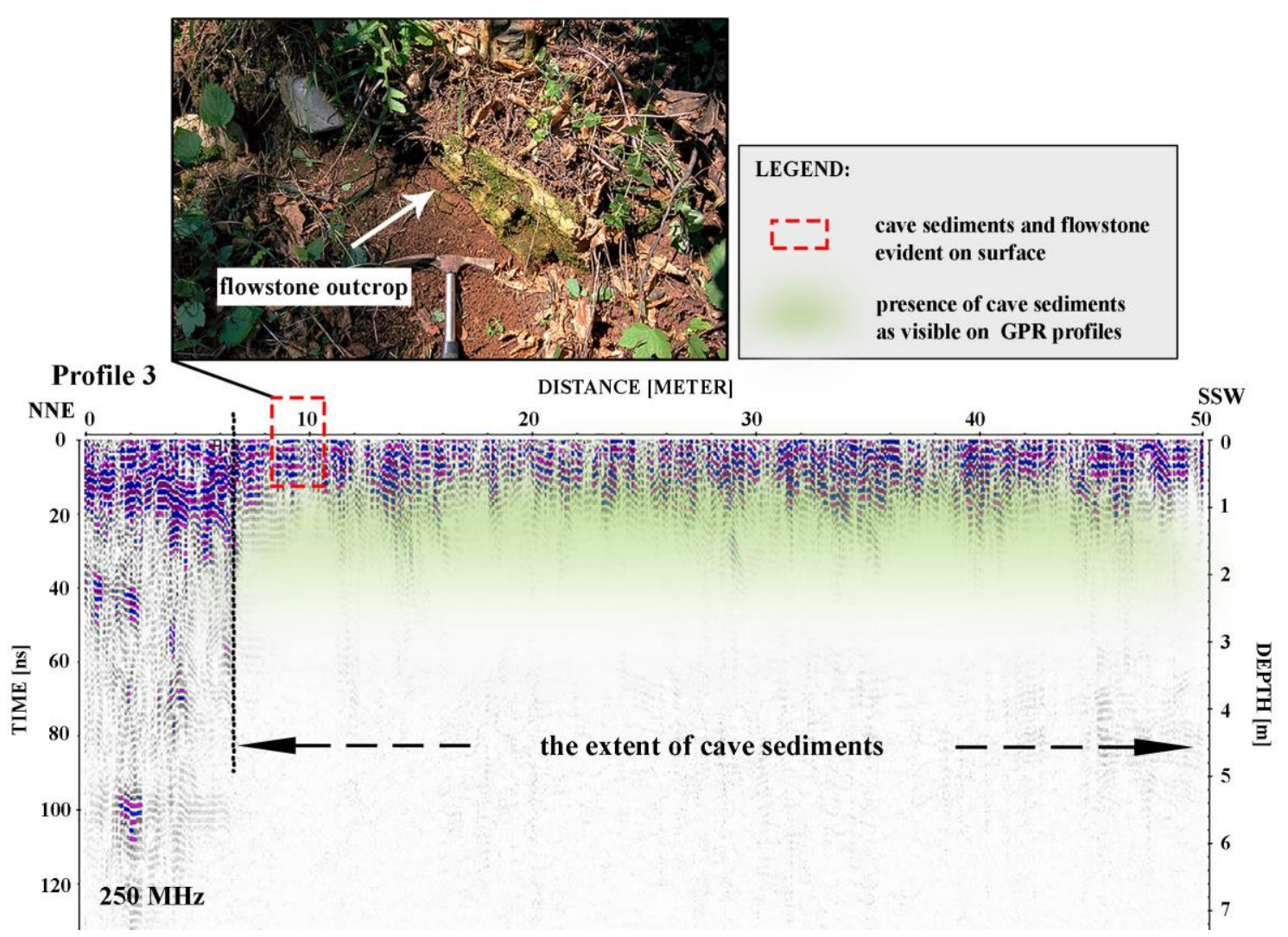

Figure 10. Radargram acquired with a $250 \mathrm{MHz}$ antenna, where the spatial extent of cave sediments was revealed along Profile 3.

\subsection{A Comparison of GPR Images Conducted in Different Time Periods}

Studying the effect of seasonal soil water dynamics on GPR signal changes is usually conducted to reveal subsurface flow dynamics and patterns [35]. In this study, profiles were measured in different site conditions to determine how a difference in water content influences the GPR data and to verify if measuring is appropriate in all time periods regardless of the weather conditions before profiling.

A comparison of radargrams conducted in various field conditions is illustrated in Figure 11. We selected only two profiles to show the results because comparisons of other profiles are quite similar. As we can see from the radargrams of Profiles 1 and $2 b$, anomalous zones (highly attenuated areas associated with cave sediments) are clearly visible regardless of the field conditions during the measuring. Comparing the radargrams of Profile 1, we can see some smaller differences in the continuity of the reflections. In very dry conditions (radargram measured in July 2016 in Figure 11a), greater continuity of a slightly dipping reflector (distance 30-40 $\mathrm{m}$ at the depth of 1-3 $\mathrm{m}$ ) can be seen in comparison to the radargram conducted in a slightly wetter but still generally dry time period (radargram measured in March 2017 in Figure 11a). On the GPR images of Profile 2b there is essentially no difference between the results of the surveys conducted in a relatively dry time period (radargram measured in March 2017 in Figure 11b) and in moderately wet field conditions (radargram measured in January in Figure 11b). We can conclude that measuring in different weather conditions does not significantly affect the quality of GPR images for the purpose of this study where detecting cave sediments was the main goal. 


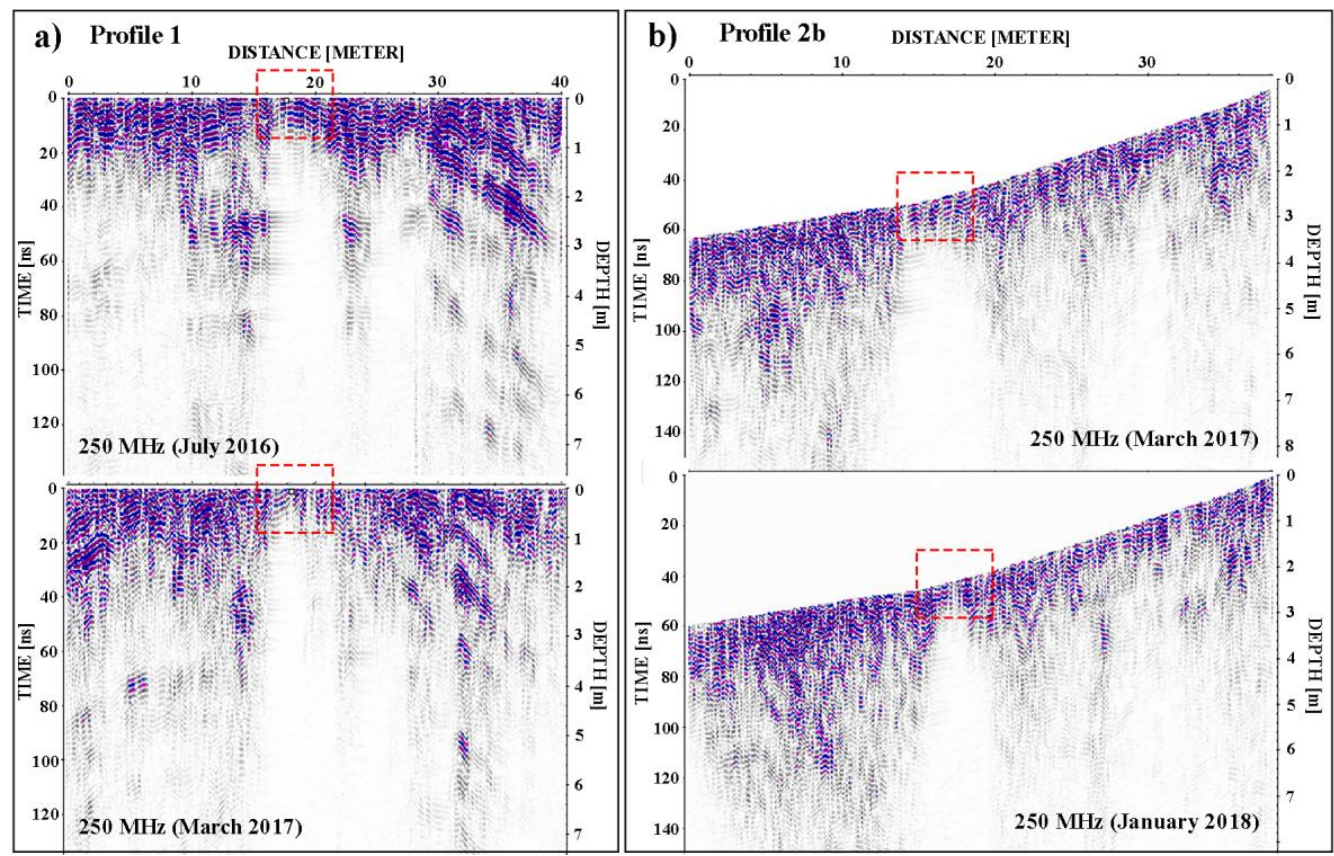

Figure 11. The GPR images obtained in various field conditions using the $250 \mathrm{MHz}$ antenna and the area of cave sediments (dashed red lines): (a) Profile 1 acquired in July 2016 (very dry field conditions) and in March 2017 (dry field conditions); (b) Profile 2b acquired in March 2017 (dry field conditions) and in January 2018 (moderately wet field conditions).

\subsection{GPR Results at Other Locations}

After profiling at the test locations, where cave sediments are clearly evident on the profile, we measured other profiles (Profiles 4, 5 and 6 presented in this study) where direct indicators for the presence of cave sediments are absent or appear only locally. Profiles were also positioned in areas where traces of water retention were observed in the field (Profiles 4 and 5).

In Profile 4, three anomalous areas are clearly seen on the radargram (Figure 12b,c). First, the concave downward anomaly in area $\mathrm{A}$ is seen at the beginning of the profile (distance $15-70 \mathrm{~m}$ in the $50 \mathrm{MHz}$ image and 22-65 $\mathrm{m}$ in the $250 \mathrm{MHz}$ image). The location of the anomaly detected by GPR corresponds with the position of the two successive elongated depressions (Figure 12a). Considering the GPR results and the geomorphological characteristics of the closer area, we concluded that this area was a depression that was filled and compacted with material during the construction of the road. Furthermore, the filled depression below the road and the two elongated depressions most probably belong to the segments of an unroofed cave, especially due to the fact that flowstone occurs in two places along the depressions on the line from the road to the entrance of Najdena cave. The concave downward reflection in the profile is completely contrary to our expectations for a filled circular depression. The study completed by Goodman and Piro [47], in which they modelled a deeply buried circular trench, revealed that the shapes recorded on raw radargrams may have a completely opposite structure in the ground and can be mistakenly interpreted as a reflection pattern due to a buried cylindrical object.

The anomalous areas B and C in Profile 4 are characterized by a strong attenuation of signal on both radargrams (Figure 12b,c). The signal amplitude is totally attenuated in area C compared to its surroundings (see signal amplitudes in Figure 12c).

After re-examining the terrain where the anomalies were detected, we observed four potential areas of water retention recognizable as slight deepenings on the road (green rectangles in Figure 12). In the immediate vicinity of the detected anomaly $\mathrm{C}$, septarian concretions also prove the presence of the cave sediments. However, only the areas of anomalies B and C detected by GPR correspond to the observed deepenings in the field. Furthermore, the locations of these two areas are also consistent 
with the surrounding topography, where highly attenuated areas B and C related to cave sediments correspond to depressions (Figure 12d,e). The recognized deepening on the road at the distance of $60 \mathrm{~m}$ is most probably connected with anomaly A.
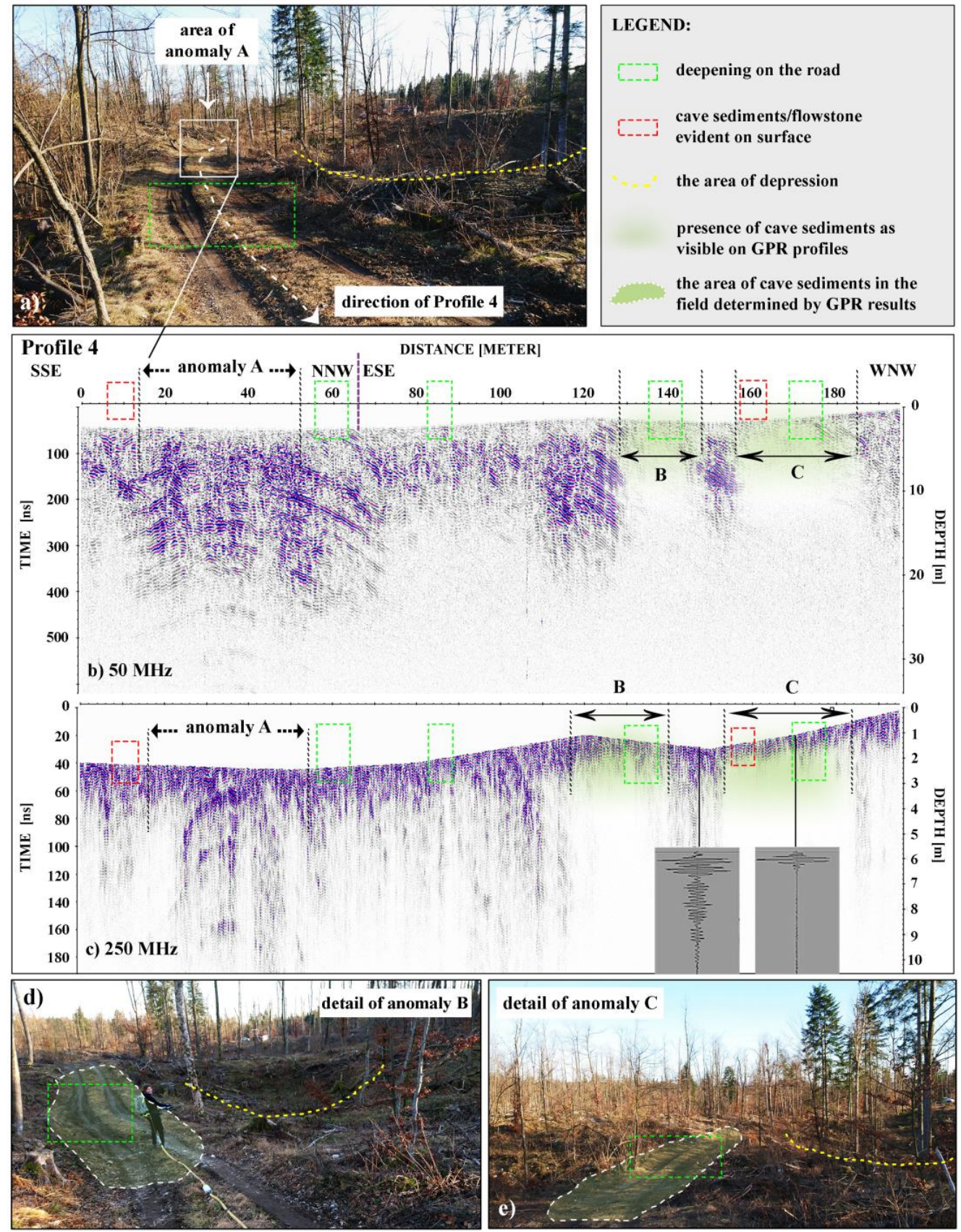

Figure 12. (a) The starting point and direction of Profile 4 with the surface depression which appears in the area of anomaly A detected by GPR. The surface deepening is also visible on the road; (b) The radargram conducted with the $50 \mathrm{MHz}$ antenna with the detected anomaly A and attenuated areas $\mathrm{B}$ and $\mathrm{C}$ interpreted as cave sediments; (c) The radargram conducted with the $250 \mathrm{MHz}$ antenna (note the vertical exaggeration 1:5) with a comparison of signal amplitudes, where the signal is strongly attenuated by the depth in the area of cave sediments even after the processing steps; (d) Surface morphology in the area of anomaly B, where the depression and the deepening on the road occur-the attenuated areas were interpreted as cave sediments; (e) The extent of cave sediments on the field as detected by GPR and the accompanying occurrences of the road deepening. 
Profile 5 was positioned on a large area of a deepening on the road, where the road needs to be frequently filled with coarse-grained material and gutters must be dug to drain the redundant water (Figure 13a). In the vicinity, large outcrops of flowstone appear on the surface on a steep slope below the road (Figure 13b,c). According to the results of the profiles at testing locations, we expected a similar GPR image with a strongly attenuated area but the radargram recorded with the $250 \mathrm{MHz}$ antenna (the same results were also obtained with the $50 \mathrm{MHz}$ antenna) does not show any clear evidence of cave sediments. The signal is slightly more attenuated in the area between 0-35 $\mathrm{m}$ compared to the other parts of the radargram (Figure 13d) but not as strongly as in Profiles 1, 2, 3 and 4 . This could be explained by the fact that a lot of material has been deposited in this area through the frequent reconstructions of the road. The strong reflection visible at the distance of $18 \mathrm{~m}$ down to the depth of $9 \mathrm{~m}$ could be the result of reflections from a larger block of filling material. However, due to the unclear results obtained by GPR, we interpreted this area as having a possible presence of cave sediments (Figure 13d).

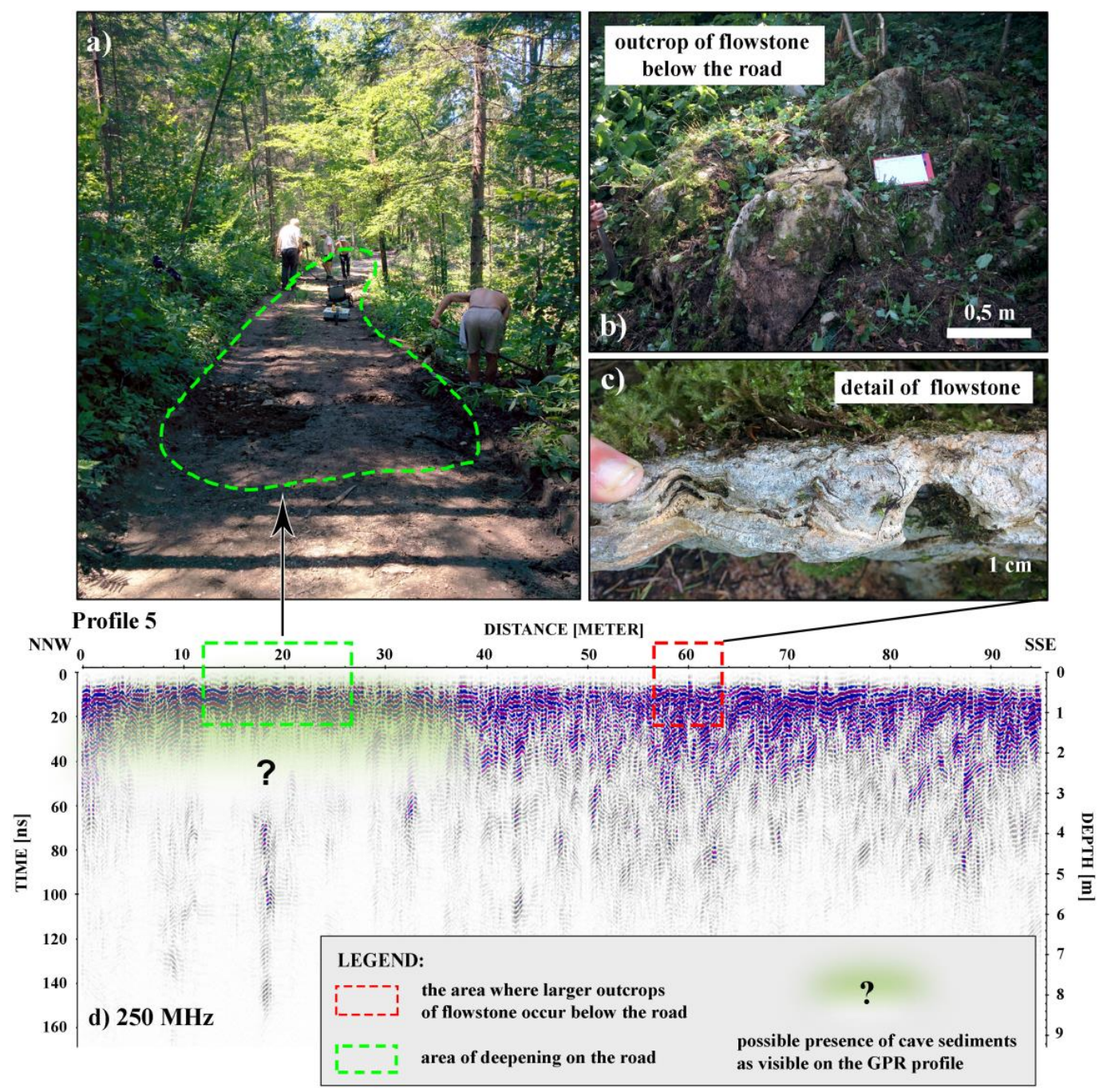

Figure 13. (a) Roadwork, where slightly deepened areas need to be filled with coarse-grained material to keep the road in function; (b) Large outcrops of flowstone occur below the road; (c) A detail of flowstone structure; (d) In the radargram of Profile 5, the area of the possible presence of cave sediments is not as obvious as in other profiles.

Profile 6 was positioned along the road to observe a possible connection with the detected attenuated area in Profile 3 and to discover other possible interconnections between different depressions. As it is visible in Figure 14, four large areas of high attenuation are evident. Superficial 
indicators for cave sediments are only evident at one location (at the distance of 235-265 m). However, the attenuated area at $155-175 \mathrm{~m}$ is almost certainly related to cave sediments, because its position corresponds to the cave sediments detected in Profile 3. The other two locations (at the distance of 105-125 m and 400-455 m) most probably belong to cave sediments as well but we should not exclude the possibility of other sedimentary regolith bodies. These areas were therefore classified as having a possible presence of cave sediments, even though there are no superficial indicators for their presence.

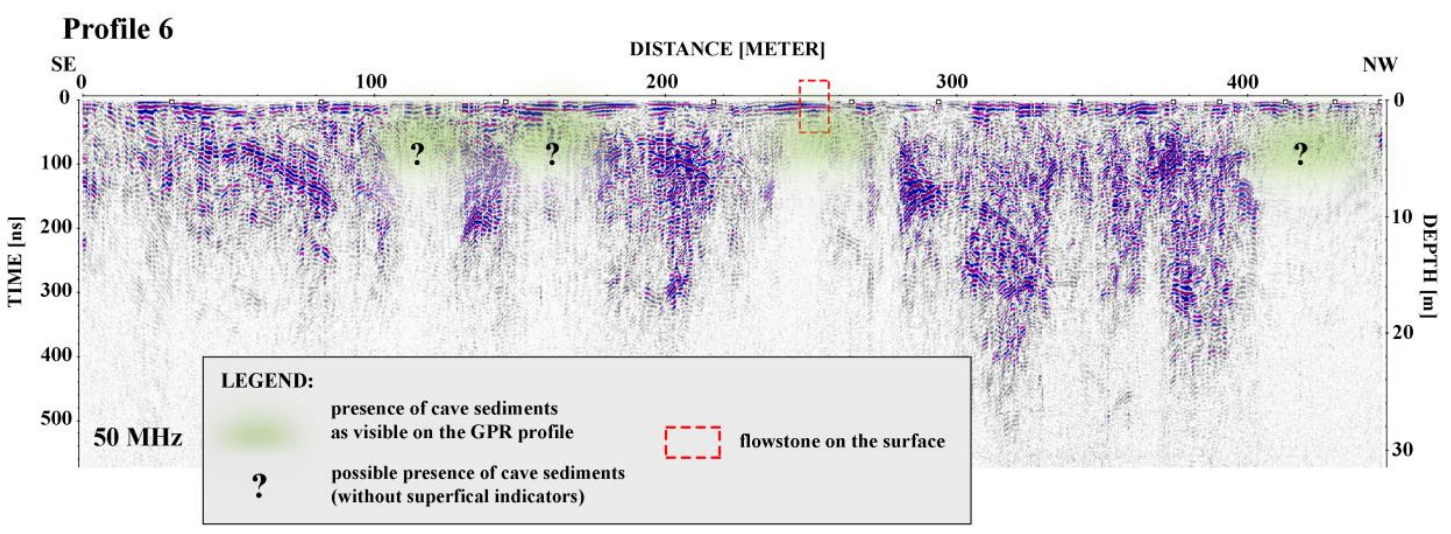

Figure 14. The radargram of Profile 6 with four detected attenuated areas. Flowstone only occurs on the surface at one location, so other locations were interpreted as "possible locations of cave sediments" (see legend). The attenuated area at the distance of 155-170 m corresponds to the direction of the cave sediments extent detected in Profile 3.

\subsection{XRD and XRF Results}

The quantitative XRD analysis shows a rather similar mineralogical composition of cave sediments and soils on carbonate rocks (rendzina), where vermiculite (Vrm), chlorite group minerals (Chl), muscovite/illite (Ms/Ill), kaolinite (Kln) and quartz (Qz) were detected in all samples (Figure 15). Hematite $(1-2 \%)$ is present in some samples of cave sediments and rutile was detected in one surface sample from V1. Na-plagioclase feldspar (7-10\%) are present only in soils on carbonate rocks.

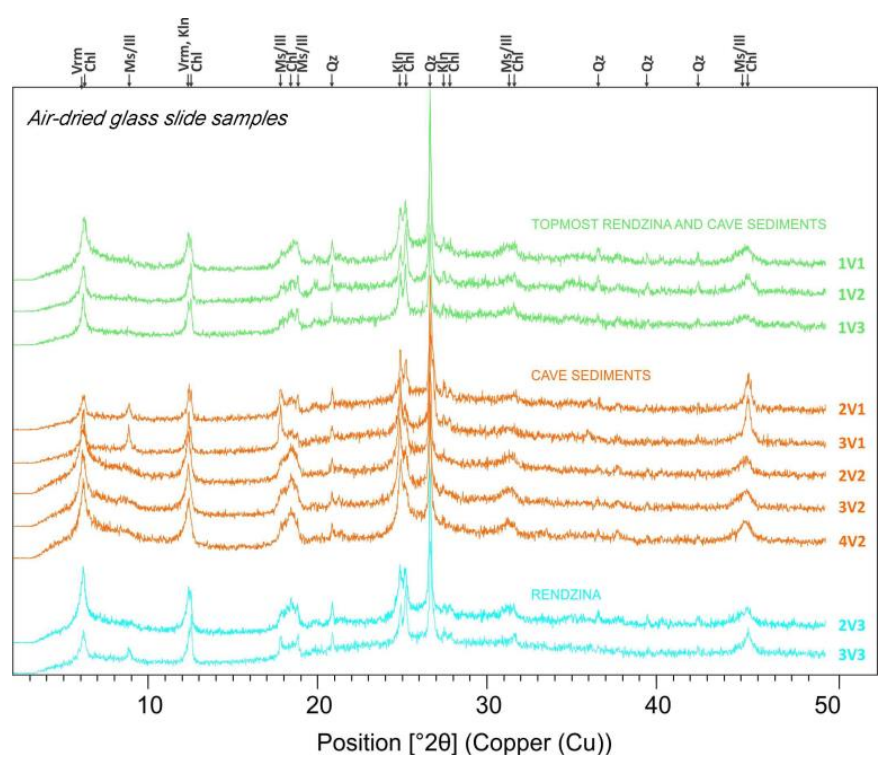

Figure 15. X-ray diffraction (XRD) patterns of air-dried oriented samples with the determined minerals (Vrm-vermiculite, Chl-chlorite group minerals, Ms/Ill-muscovite/illite, Kln-kaolinite, Qz-quartz). 
Principal component analysis (Figure 16) explained $64.63 \%$ of the variance in the data by the first two components (PCA1 and PCA2). It is a procedure for finding hypothetical components that account for as much of the variance in multidimensional data as possible [48]. Samples from location V3 are associated with the high values of $\mathrm{Si}, \mathrm{Sr}, \mathrm{Mg}$ and Ca related to the well-crystallized carbonates, Na-plagioclase feldspar, quartz and chlorite group minerals. These samples also contain lesser amounts of clay minerals (kaolinite, illite and vermiculite). A high proportion of $\mathrm{Al}, \mathrm{Fe}, \mathrm{Mn}, \mathrm{Ti}, \mathrm{S}, \mathrm{Rb}, \mathrm{Ba}, \mathrm{As}$, $\mathrm{Zn}, \mathrm{Zr}, \mathrm{Nb}, \mathrm{Cu}, \mathrm{Pb}$ and Mo belongs to samples of cave sediments (V1 and V2). Most of them are related with clays (Kln, Vrm), as well as $\mathrm{Fe} / \mathrm{Al} / \mathrm{Ti}$ oxides/hydroxides. $\mathrm{Fe} / \mathrm{Al} / \mathrm{Ti}$ oxides/hydroxides were not detected by XRD due to broad reflections and poor crystallinity of such minerals.

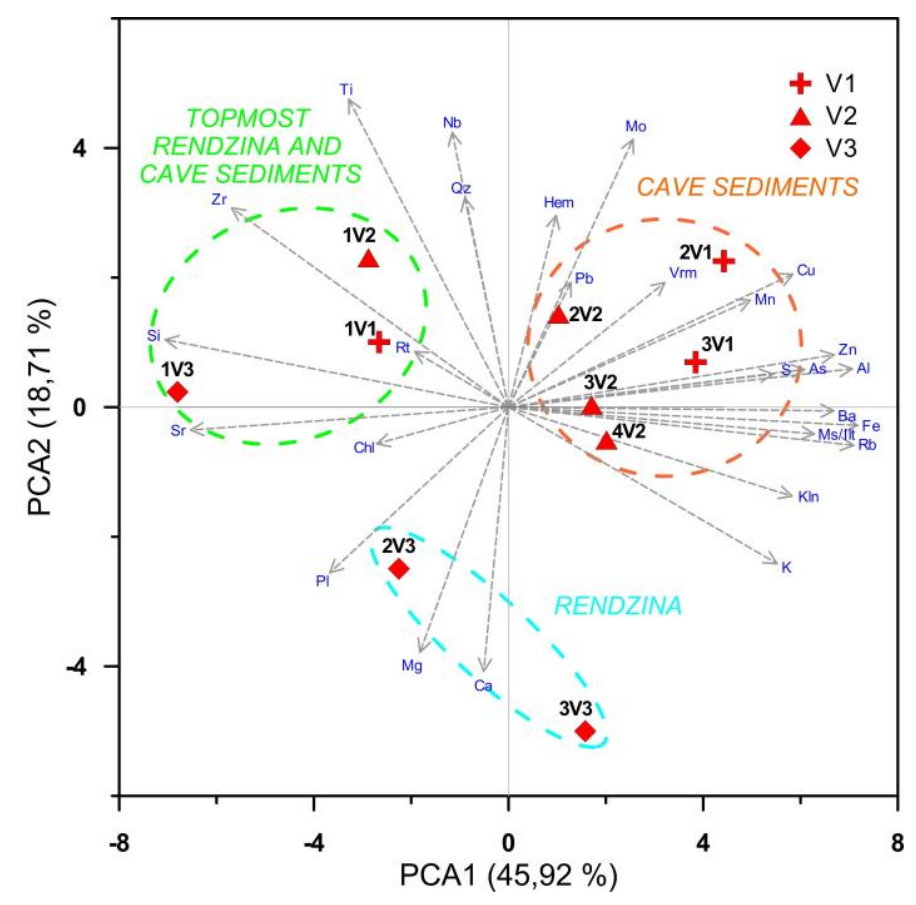

Figure 16. PCA (Principal Component Analysis) diagram for the overall XRF and XRD datasets.

\subsection{Integration of Results}

The synthesis of results from different methods used in this study is shown in Figure 17. For a comprehensive determination, many techniques and methods should be used to minimize the ambiguities in interpretation. Field work, which includes geomorphological mapping and locating all surface indicators of speleogenesis on a LiDAR map, is very important. Based on terrain observations, GPR profiling can be properly planed and locations for the mineralogical and geochemical analyses can be selected. For a proper reconstruction of unroofed cave systems, each location of cave sediments must be specifically investigated due to heterogeneous mineral composition of the cave sediments. The lateral comparison of signal attenuation between the cave sediments and soils in surrounding proved to be very good indicator for the cave sediments presence. However, signal attenuation can occur also in areas of filled shafts or other regolith bodies. Due to the very complex and heterogeneous characteristics of karst underground system, which is full of voids, different features of various sizes and shapes, automatic recognition of cave sediments cannot be provided. Besides that, cave sediments can have very heterogeneous mineral composition and their extent can be of various size and shape. In order to provide possible automation of the proposed procedure (e.g., [49]), additional mineralogical-geochemical analyses should be done in the future and the electrical resistivity tomography (ERT) as a complementary method can be conducted in the further research. However, 
due to the locally rough karst terrain and the time-consuming nature of ERT, we decided to apply only the GPR method for the purpose of this study.

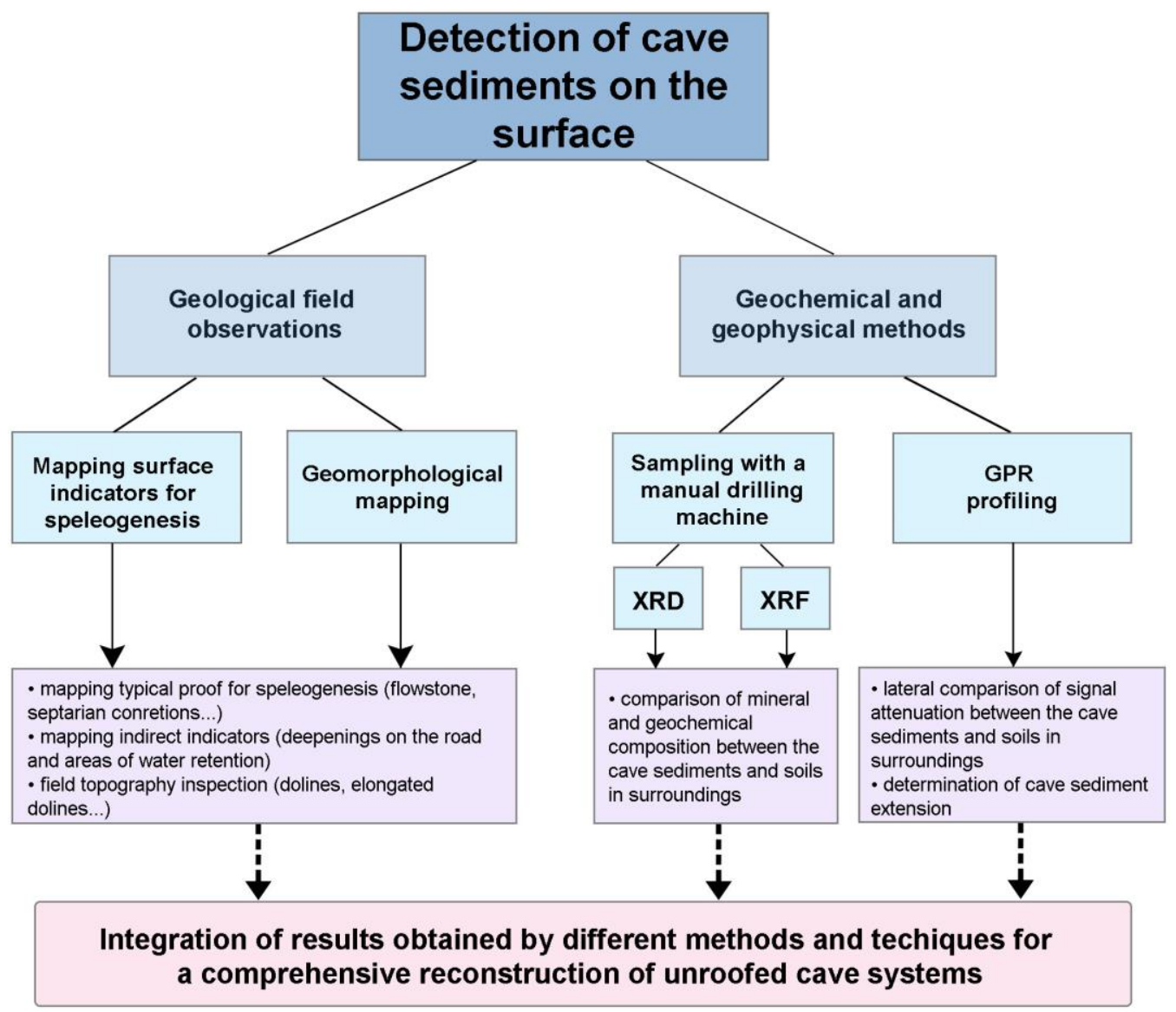

Figure 17. Diagram shows the used methods with the main results, as needed to delineate unroofed cave systems into a whole.

\section{Discussion}

Cave sediments at all testing locations (Profiles 1, 2 and 3), where outcrops of flowstone indicate their presence, are clearly shown as highly attenuated areas on radargrams (Figures 7, 8 and 10). Signal amplitude is completely attenuated and the depth of penetration consequently restricted in these areas (Figures 7c and 12c). As field examinations and geological mapping are mostly insufficient to follow the extent of cave sediments in the whole area of interest, due to limited occurrences of indicators on the surface, GPR proved to be a very useful tool to determine their spatial extent. The spatial extent of cave sediments and the direction of the unroofed cave system were determined in two testing locations (see Profiles $2 \mathrm{a}, 2 \mathrm{~b}$ and 3 in Figures $8 \mathrm{~b}$ and 10).

The relatively complex terrain of the study area, full of dolines, complicates the task of recognizing the various features as a cohesive whole model, compared to unroofed cave systems observed in Classical Karst, where segments of unroofed cave systems are easier to identify (e.g., [1,2,5,7]). To study the location, size and shape of unroofed caves, high-resolution LiDAR data proved to be very useful [2]. Where LiDAR data are not available, aerial photos can also be an indispensable tool in planning the proper location of GPR profiles [13]. Nowadays, remotely gathered data (e.g., LiDAR) in conjunction with the ground penetrating radar method and field observations enable easier and comprehensive studying of various geomorphological issues [50-58]. Previously unrecognized geomorphological features can now be revealed by LiDAR data in combination with different geophysical methods. It is important to note that all GPR results should be correlated and integrated with field topography 
observations. The extent of cave sediments derived from GPR profiling was further placed on the LiDAR image to facilitate the final interpretation (Figure 18). In addition, the terrain was meticulously re-examined after GPR measurements to determine any possible connections of the detected anomalies with the surrounding topography (Figures 9 and 12a,d,e).

Cave sediments were also clearly evident in other GPR profiles, where cave sediments or flowstone occur only occasionally in the vicinity of the GPR lines. All detected anomalies visible as highly attenuated areas in the presented profiles are related to the larger sedimentary regolith bodies. In the areas where superficial indicators complement their speleogenetic origin, these thicker sediment occurrences can be defined as cave sediments (Figures 12 and 13).

However, it should be noted that it is not always possible to distinguish between various larger regolith bodies filled with sediments on the basis of their mineralogy. Due to their vertical shape, only karst cutters can collect sufficient insoluble residue, all other accumulation of regolith bodies must be admixed materials of diverse origins or be completely allogenic in origin [20]. With GPR we can detect the increased thickness of sediments, while the sediments can be of various origins. In karst environments, the origin of various surface features cannot always be determined but anomalous areas detectable by GPR contribute to the information which is otherwise often invisible from the surface.

During the extensive research, measurements were carried out in different field conditions to observe how cave sediments reflect on the radargrams depending on different water content. Loamy and clayey materials strongly attenuate radar signals, so various horizons or layers of soil materials cannot be distinguished when their electrical properties are too similar. The penetration depths can be severely restricted in clayey materials in areas of karst [37,59]. However, such attenuated areas can be good indicators for the presence of thicker sediments, which is important evidence in detecting unroofed caves [13].

The depth range of GPR surveys is dependent mostly on field conditions including hydrogeological characteristics, climate and weather conditions (moisture content, infiltration, subsurface water flow, etc.) and many other factors. The impact of the above-mentioned factors on the characteristics of a certain terrain is very complex, especially in karst environments. Only a small number of published papers studies the influence of seasonal changes in soil moisture on GPR data [60-64]. Slowik [62] demonstrated that the depths of penetration were highest at low groundwater levels but the depth range containing useful information was the same as at high water levels. Furthermore, Slowik [65] conducted GPR on fluvial, lacustrine and anthropogenic landforms to determine the influence of hydrogeological conditions, silt content and measurements parameter settings on depth range and resolution. He determined that the highest depths of penetration were reached at low groundwater levels but some sedimentary structures were better imaged at high groundwater levels. Zhang et al. [35] showed that GPR reflections between different horizon interfaces became clearer as soil became wetter at one test location, while GPR reflections in the soil-bedrock interface and the weathered-unweathered rock interface became intermittent as soil became wetter at another test location. From the results of different studies, we can conclude that water content related to seasonal changes can have different effects on the GPR image. The results of the mentioned studies demonstrate the value of repeated GPR surveys in different field conditions to select the optimal time for GPR surveys for the specific terrain conditions and for a better insight in the interpretation of radargrams. However, the results of our study show that different field conditions did not substantially affect the quality of GPR data when detecting cave sediments which are highly conducted materials by themselves, irrespective of the water content during measuring.

The mineralogy of cave sediments and soils on carbonate rocks is similar, there are only small variations in the abundance of each mineral. Mineral composition of cave sediments includes more clay minerals (kaolinite, illite and vermiculite) and iron/aluminium oxides/hydroxides. Hematite causing the red colour was detected in some samples of cave sediments, while Na-plagioclase feldspar only occurred in soils on carbonate rocks. However, the mentioned differences in mineralogy, especially the proportion and the type of clay minerals and a higher content of $\mathrm{Fe}, \mathrm{Mn}$ and $\mathrm{Al}$ elements, most likely contribute to increased attenuation in cave sediments compared to soils on carbonate rocks. However, mineral 
composition of soils and an abundance of different minerals play an important role in the performance of GPR. For example, Breiner et al. [22] observed that soils on a bedrock in granitic terrain, which contains more mafic minerals (5\% hornblende, $20 \%$ biotite), are more attenuating compared to soils on a bedrock where mafic mineral content is lower ( $<1 \%$ hornblende and $20 \%$ biotite). They concluded that especially increased biotite content severely restricts the performance of GPR. Van Dam et al. [66] discovered that iron oxides lower electromagnetic wave velocity. Further laboratory analyses proved that the amount of iron oxide in a material correlates with volumetric water content and, therefore with dielectric properties. The correlation is caused by the larger specific surface and capillary-retention capacity of iron oxides like goethite and can thus have a profound influence on the GPR signal [66].

Based on the results of this study we can conclude that in addition to the thickness of the cave sediments, small differences in the amounts of a particular type of clay minerals can affect attenuation in the soils. Even very small quantities of hematite and other iron oxides and hydroxides greatly increase the overall soil conductivity. Apart from that, all mentioned factors indirectly affect increased water retention in areas of cave sediments compared to their surroundings. Variations in the abundance of clay minerals and a consequently higher water content severely restrict GPR signal propagation.

Distinction between cave sediments and other regolith bodies (sediments in dolines, filled shafts, cutters) in karst can be very difficult, especially since cave sediments can be very heterogeneous and similar to the soils as the product of bedrock weathering. For that reason, attenuated areas detected by GPR were labelled as having a possible presence of cave sediments, where superficial indicators for their presence are absent (Figure 18). GPR has limitations when the size of regolith bodies and their mineral composition are too similar, therefore caution is needed when interpreting the results. On the basis of GPR data in combination with geomorphological mapping and LiDAR data, certain karst features can be interconnected. However, additional profiles (outside forest paths) should be conducted in order to gain information needed for a proper determination of the geometrical extent of unroofed cave systems.

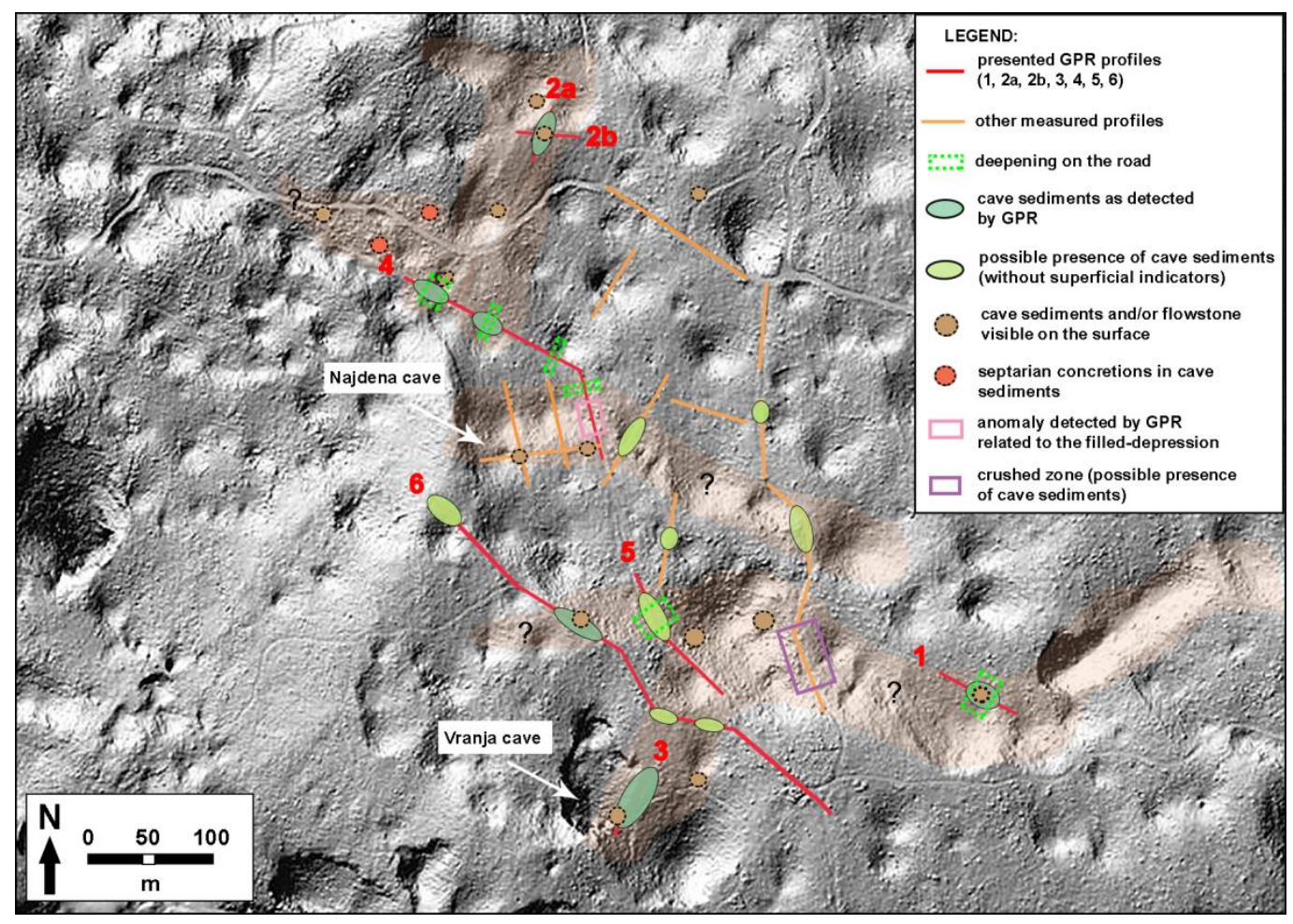

Figure 18. Profiles with interpreted anomalies detected by GPR and the occurrences of the superficial indicators of cave sediments. 


\section{Conclusions}

Systematic mapping of unroofed cave features such as cave sediments and flowstones can yield a better insight into the spatial distribution of cave systems. It can contribute to the knowledge of former underground cave systems, their history and most importantly, to a better understanding of the karst development in the sense of an interconnection between the underground and the surface. Any new information helps us determine the origin of surface features including the most common form, a doline, the formation of which is still not clearly understood. Outcrops of cave sediments and other regolith bodies are usually limited in spatial extent, covered or completely reshaped due to surface processes. Most of the indicators for unroofed caves disappear over time. In areas where direct indicators for unroofed caves, such as cave sediments and flowstones, are preserved only locally, GPR has proven to be a useful method to determine the spatial extent of cave sediments. Results obtained by geological and geomorphological mapping in combination with GPR can thus help us recognize individual cave systems and reconstruct the direction of the former underground streams.

The results of XRD and XRF analyses show that mineralogical-geochemical characteristics of cave sediments are not obviously different from the characteristics of soils on carbonate rocks. However, we found that minor changes in mineralogical composition and an abundance of clay minerals can strongly affect the GPR image. The quantity and type of clay minerals are important factors affecting the dielectric properties and attenuation in the soil. As observed, minor differences can lead to significant changes in signal penetration.

Furthermore, greater amounts of clay minerals and the presence of small amounts of iron and aluminium oxides as well as hydroxides control the water quantity and its retention time in the soil, which are the key factors for increased attenuation in the areas of cave sediments.

Further detailed XRD analyses with changes such as a longer scanning time, Mg and K-saturation as well as glycerol solvation are in progress to distinguish all types of clay and mix-layered clay minerals. Some additional explorations of different locations for GPR profiling and for further mineralogical-geochemical analyses are planned since the mineral composition of cave sediments is quite heterogeneous. The suggested surveys will contribute to a better understanding of the impact of the mineralogical-geochemical composition on the GPR performance in sediments, where mineral composition and consequently a certain proportion of water are of great importance for material conductivity properties.

Acknowledgments: This study was conducted with the support of the research Program P1-0011 and the Ph.D. grant 1000-15-0510 financed by the Slovenian Research Agency. This work also benefited from networking activities carried out within the EU-funded COST Action TU1208 "Civil Engineering Applications of Ground Penetrating Radar." The authors are grateful to members of the Society for Cave Exploration from Ljubljana for their contribution during field measuring. We would also like to thank Jaka Flis for field assistance and France Šušteršič for comments and advice during the preparation of this paper and for sharing his field experience in karstology of the study area. We also highly appreciate the copy edits done by Kaja Bucik Vavpetič.

Author Contributions: Teja Čeru acquired and processed the GPR data and wrote Sections 1, 2, 3.3, 4.1-4.3, 4.5, 5 and 6. Matej Dolenec did the mineralogical and geochemical analyses and wrote Sections 3.2, 3.3 and 4.4. Andrej Gosar contributed to GPR measurements and data processing as well as to the preparation of the manuscript.

Conflicts of Interest: The authors declare no conflicts of interest.

\section{References}

1. Knez, M.; Slabe, T. Unroofed caves and recognising them in karst relief (discovered during motorway construction at Kozina, South Slovenia). Acta Carsol. 1999, 28, 103-112. [CrossRef]

2. Mihevc, A. Uporaba Lidarskih Posnetkov v Geomorfologiji Krasa na Primeru Brezstropih Jam. Zbornik Posvetovanja Raziskave s Področja Geodezije in Geofizike 2015; Slovensko združenje za geodezijo in geofiziko: Ljubljana, Slovenia, 2015; pp. 141-149.

3. Mihevc, A. Brezstropa jama pri Povirju. Naše Jame 1996, 38, 65-75.

4. Mihevc, A. Speleogeneza Divaškega Krasa; ZRC: Ljubljana, Slovenia, 2001; p. 180. 
5. Mihevc, A.; Slabe, T.; Šebela, S. Denuded caves: An inherited element in the karst morphology; the case from Kras. Acta Carsol. 1998, 27, 165-174.

6. Šušteršič, F. Interaction between a cave system and the lowering karst surface; case study: Laški ravnik. Acta Carsol. 1998, 27, 115-138. [CrossRef]

7. Knez, M.; Slabe, T. Unroofed caves are an important feature of karst surfaces: Examples from the classical karst. Z. Geomorphol. 2002, 46, 181-191.

8. Mais, K. Roofless caves, a polygenetic status of cave development with special references to cave regions in the Eastern Calcareous Alps in Salzburg and Central Alps, Austria. Acta Carsol. 1999, 28, 145-158. [CrossRef]

9. Osborne, R.A.L. Karst geology of Wellington Caves: A review. Helictite 2001, 37, 3-12.

10. Klimchouk, A. Cave un-roofing as a large-scale geomorphic process. Speleogenesis Evolution Karst Aquifers 2006, 4, 1-11.

11. Ufrecht, W. Evaluating landscape development and karstification of the Central Schwäbische Alb (Southwest Germany) by fossil record of karst fillings. Z. Geomorphol. 2008, 52, 417-436. [CrossRef]

12. Knez, M.; Slabe, T. Cave Exploration in Slovenia: Discovering Over 350 New Caves during Motorway Construction on Classical Karst, (Cave and Karst Systems of the World); Springer: Cham, Switzerland, 2016; p. 324.

13. Čeru, T.; Šegina, E.; Knez, M.; Benac, Č.; Gosar, A. Detecting and characterizing unroofed caves by ground penetrating radar. Geomorphology 2018, 303, 524-539. [CrossRef]

14. White, W.B. Cave sediments and paleoclimate. J. Cave Karst Stud. 2007, 69, 76-93.

15. Zupan Hajna, N.; Pruner, P.; Mihevc, A.; Schnabl, P.; Bosák, P. Cave sediments from the Postojnska-Planinska cave system (Slovenia): Evidence of multi-phase evolution in epiphreatic zone. Acta Carsol. 2008, 37, 63-86. [CrossRef]

16. Sasowsky, I.D. Clastic sediments in caves-Imperfect recorders of processes in karst. Acta Carsol. 2007, 36, 143-149. [CrossRef]

17. Arriolabengoa, M.; Iriarte, E.; Aranburu, A.; Yusta, I.; Arrizabalaga, A. Provenance study of endokarst fine sediments through mineralogical and geochemical data (Lezetxiki II cave, northern Iberia). Quat. Int. 2015, 364, 231-243. [CrossRef]

18. Martini, I. Cave clastic sediments and implications for speleogenesis: New insights from the Mugnano cave (Montagnola Senese, Northern Apennines, Italy). Geomorphology 2011, 134, 452-460. [CrossRef]

19. Bónová, K.; Bella, P.; Bóna, J.; Spišiak, J.; Kováčik, M.; Kováčik, M.; Petro, L. Heavy minerals in sediments from the Mošnica Cave: Implications for the pre-Quaternary evolution of the middle-mountain allogenic karst in the Nízke Tatry Mts., Slovakia. Acta Carsol. 2014, 43, 297-317. [CrossRef]

20. Šušteršič, F.; Rejšek, K.; Mišič, M.; Eichler, F. The role of loamy sediment (terra rossa) in the context of steady state karst surface lowering. Geomorphology 2009, 106, 35-45. [CrossRef]

21. Mihevc, A.; Zupan Hajna, N. Clastic sediments from dolines and caves found during the construction of the motorway near Divača, on the Classical Karst. Acta Carsol. 1996, 25, 169-191.

22. Breiner, J.M.; Doolittle, J.A.; Horton, R.M.; Graham, R.C. Performance of ground-penetrating radar on granitic regoliths with different mineral composition. Soil Sci. 2011, 176, 435-440. [CrossRef]

23. Van Dam, R.M.; Hendrickx, J.M.H.; Cassidy, N.J.; North, R.E.; Dogan, M.; Borchers, B. Effects of magnetite on high-frequency ground-penetrating radar. Geophysics 2013, 78, H1-H11. [CrossRef]

24. Van Dam, R.L. Causes of ground-penetrating radar reflections in sediment. Ph.D. Thesis, Vrije Universiteit, Amsterdam, The Netherlands, 2001; p. 101.

25. Čar, J. Geološka zgradba požiralnega obrobja Planinskega polja (Geological setting of the Planina polje ponor area). Acta Carsol. 1981, 10, 75-105.

26. Šušteršič, F. A conceptual model of dinaric solution doline dynamics. Cave Karst Sci. 2017, 44, 66-75.

27. Buser, S.; Grad, K.; Pleničar, M. Basic Geological Map of Yugoslavia, Sheet Postojna, L33-77; Federal Geological Survey of Beograd: Beograd, Srbija, 1967.

28. LiDAR (Public Information of Slovenia, the Surveying and Mapping Authority of the Republic of Slovenia, LiDAR, 2015) ARSO, Ministry of the Environment. Available online: http:/ /gis.arso.gov.si/evode/profile. aspx?id=atlas_voda_Lidar@Arso (accessed on 5 March 2018).

29. Šušteršič, F. Cave Sediments and Denuded Caverns in the Laški Ravnik, Classical Karst of Slovenia. In Studies of Cave Sediments: Physical and Chemical Records of Paleoclimate; Sasowsky, I.D., Mylroie, J., Eds.; Springer: New York, NY, USA, 2004; pp. 123-134. 
30. Silva, O.L.; Bezerra, F.H.R.; Maia, R.P.; Cazarin, C.L. Karst landforms revealed at various scales using LiDAR and UAV in semi-arid Brazil: Consideration on karstification processes and methodological constraints. Geomorphology 2017, 295, 611-630. [CrossRef]

31. Kruse, S.; Grasmueck, M.; Weiss, M.; Viggiano, D. Sinkhole structure imaging in covered karst terrain. Geophys. Res. Lett. 2006, 33, L16405. [CrossRef]

32. Pueyo-Anchuela, Ó.; López Julián, P.L.; Casas-Sainz, A.M.; Liesa, C.L.; Pocoví-Juan, A.; Ramajo Cordero, J.; Perez Benedicto, J.A. Three dimensional characterization of complex mantled karst structures. Decision making and engineering solutions applied to a road overlying evaporite rocks in the Ebro Basin (Spain). Eng. Geol. 2015, 193, 158-172. [CrossRef]

33. Guidry, S.A.; Grasmueck, M.; Carpenter, D.G.; Gombos, A.M. Jr.; Bachtel, S.L.; Viggiano, D.A. Karst and early fracture networks in carbonates, Turks and Caicos Islands, British West Indies. J. Sediment. Res. 2007, 77, 508-524. [CrossRef]

34. Fernandes, A.L.; Medeiros, W.E.; Bezerra, F.H.R.; Oliveira, J.G.; Cazarin, C.L. GPR investigation of karst guided by comparison with outcrop and unmanned aerial vehicle imagery. J. Appl. Geophys. 2015, 112, 268-278. [CrossRef]

35. Zhang, J.; Lin, H.; Doolittle, J. Soil layering and preferential flow impacts on seasonal changes of GPR signals in two contrasting soils. Geoderma 2014, 213, 560-569. [CrossRef]

36. Simeoni, M.A.; Galloway, P.D.; O'Neil, A.J.; Gilkes, R.J. A procedure for mapping the depth to the texture contrast horizon of duplex soils in south-western Australia using ground penetrating radar, GPRS and kriging. Aust. J. Soil Res. 2009, 47, 613-621. [CrossRef]

37. Doolittle, J.A.; Collins, M.E. A comparison of EM induction and GPR methods in areas of karst. Geoderma 1998, 85, 83-102. [CrossRef]

38. Stroh, J.C.; Archer, S.; Doolittle, J.A.; Wilding, L. Detection of edaphic discontinuities with ground-penetrating radar and electromagnetic induction. Landsc. Ecol. 2001, 16, 377-390. [CrossRef]

39. Čeru, T.; Šegina, E.; Gosar, A. Geomorphological Dating of Pleistocene Conglomerates in Central Slovenia Based on Spatial Analyses of Dolines Using LiDAR and Ground Penetrating Radar. Remote Sens. 2017, 9, 1213. [CrossRef]

40. Gish, T.J.; Walthall, C.L.; Daughtry, C.S.; Kung, K.J. Using soil moisture and spatial yield patterns to identify subsurface flow pathways. J. Environ. Qual. 2005, 34, 274-286. [CrossRef] [PubMed]

41. Huisman, J.A.; Snepvangers, J.J.J.C.; Bouten, W.; Heuvelink, G.B.M. Mapping spatial variation in surface soil water content: Comparison of ground-penetrating radar and time domain reflectometry. J. Hydrol. 2002, 269, 194-207. [CrossRef]

42. Kowalsky, M.B.; Finsterle, S.; Rubin, Y. Estimating flow parameter distributions using ground-penetrating radar and hydrological measurements during transient flow in the vadose zone. Adv. Water Res. 2004, 27, 583-599. [CrossRef]

43. Jol, H.M. Ground Penetrating Radar: Theory and Applications, 1st ed.; Elsevier Science: Amsterdam, The Netherlands, 2009; p. 524.

44. Ehsani, M.R.; Daniels, J.J.; Allred, B.J. Handbook of Agricultural Geophysics, 1st ed.; CRC Press: Boca Raton, FL, USA, $2008 ;$ p. 432.

45. Waltham, T.; Bell, F.; Culshaw, M. Sinkoles and Subsidence. Karst and Cavernous Rocks in Engineering and Construction; Springer: Berlin, Germany, 2010; pp. 181-204.

46. Moore, D.M.; Reynolds, R.C. X-Ray Diffraction and the Identification and Analysis of Clay Minerals, 2nd ed.; Oxford University Press: Oxford, UK; New York, NY, USA, 1997; p. 378.

47. Goodman, D.; Piro, S. GPR Remote Sensing in Archaeology, Geotechnologies and the Environment; Springer: Heidelberg, Germany, 2013.

48. Krebs, C.J. Ecological Methodology; Addison Wesly Longman: New York, NY, USA, 1998.

49. Li, W.; Cui, X.; Guo, L.; Chen, J.; Chen, X.; Cao, X. Tree Root Automatic Recognition in Ground Penetrating Radar Profiles Based on Randomized Hough Transform. Remote Sens. 2016, 8, 430. [CrossRef]

50. Bernhardson, M.; Alexanderson, H. Early Holocene dune field development in Dalarna, central Sweden: A geomorphological and geophysical case study. Earth Surf. Process. Landf. 2017, 42, 1847-1859. [CrossRef]

51. Sinclair, S.N.; Licciardi, J.M.; Campbell, S.W.; Madore, B.M. Character and origin of De Geer moraines in the Seacoast region of New Hampshire, USA. J. Quaternary Sci. 2018, 33, 225-237. [CrossRef] 
52. Nooren, K.; Hoek, W.Z.; Winkels, T.; Huizinga, A.; Van der Plicht, H. The Usumacinta-Grijalva beach-ridge plain in southern Mexico: A high-resolution archive of river discharge and precipitation. Earth Surf. Dynam. 2017, 5, 529-556. [CrossRef]

53. Oliver, T.S.N.; Tamura, T.; Hudson, J.P.; Woodroffe, C.D. Integrating millennial and interdecadal shoreline changes: Morpho-sedimentary investigation of two prograded barriers in southeastern Australia. Geomorphpology 2017, 288, 129-147. [CrossRef]

54. Kasprzak, M.; Sobczyk, A. Searching for the void: Improving cave detection accuracy by multi-faceted geophysical survey reconciled with LiDAR DTM. Z. Geomorphol. 2017, 61, 45-59. [CrossRef]

55. Helfricht, K.; Kuhn, M.; Keuschnig, M.; Heilig, A. Lidar snow cover studies on glaciers in the Ötztal Alps (Austria): Comparison with snow depths calculated from GPR measurements. Cryosphere 2014, 8, 41-57. [CrossRef]

56. Colucci, R.R.; Forte, E.; Boccali, C.; Dossi, M.; Lanza, L.; Pipan, M.; Guglielmin, M. Evaluation of internal structure, volume and mass of glacial bodies by integrated lidar and ground penetrating radar surveys: The case study of Canin eastern glacieret (Julian Alps, Italy). Surv. Geophys. 2015, 36, 231-252. [CrossRef]

57. Malehmir, A.; Andersson, M.; Mehta, S.; Brodic, B.; Munier, R.; Place, J.; Maries, G.; Smith, C.; Kamm, J.; Bastani, M.; et al. Post-glacial reactivation of the Bollnäs fault, central Sweden-A multidisciplinary geophysical investigation. Solid Earth 2016, 7, 509-527. [CrossRef]

58. Bubeck, A.; Wilkinson, M.; Roberts, G.P.; Cowie, P.A.; McCaffrey, K.J.W.; Phillips, R.; Sammonds, P. The tectonic geomorphology of bedrock scarps on active normal faults in the italian apennines mapped using combined ground penetrating radar and terrestrial laser scanning. Geomorphology 2015, 237, 38-51. [CrossRef]

59. Leucci, G.; Margiotta, S.; Negri, S. Geophysical and geological investigations in a karstic environment (Salice Salentino, Lecce, Italy). J. Environ. Eng. Geophys. 2004, 9, 25-34. [CrossRef]

60. Boll, J.; van Rijn, R.P.G.; Weiler, K.W.; Ewen, J.A.; Daliparthy, J.; Herbert, S.J.; Steenhuis, T.S. Using ground-penetrating radar to detect layers in a sandy field soil. Geoderma 1996, 70, 117-132. [CrossRef]

61. Lunt, I.A.; Hubbard, S.S.; Rubin, Y. Soil moisture content estimation using ground-penetrating radar reflection data. J. Hydrol. 2005, 307, 254-269. [CrossRef]

62. Słowik, M. Influence of measurement conditions on depth range and resolution of GPR images: The example of lowland valley alluvial fill (the Obra River, Poland). J. Appl. Geophys. 2012, 85, 1-14. [CrossRef]

63. Tatum, D.; Francke, J. Radar suitability in aeolian sand dunes-A global review. In Proceedings of the 14th International Conference on Ground Penetrating Radar, Shanghai, China, 4-8 June 2012; Volume III, pp. 1-706. [CrossRef]

64. Truss, S.; Grasmueck, M.; Vega, S.; Viggiano, D.A. Imaging rainfall drainage within the Miami oolitic limestone using high-resolution time-lapse ground-penetrating radar. Water Resour. Res. 2007, 43, 1-15. [CrossRef]

65. Słowik, M. Analysis of fluvial, lacustrine and anthropogenic landforms by means of ground-penetrating radar (GPR): Field experiment. Near Surf. Geophys. 2014, 12, 777-791. [CrossRef]

66. Van Dam, R.L.; Schlager, W.; Dekkers, M.J.; Huisman, J.A. Iron oxides as a cause of GPR reflections. Geophysics 2002, 67, 536-545. [CrossRef]

(C) 2018 by the authors. Licensee MDPI, Basel, Switzerland. This article is an open access article distributed under the terms and conditions of the Creative Commons Attribution (CC BY) license (http://creativecommons.org/licenses/by/4.0/). 